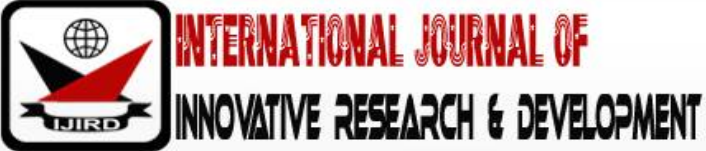

ISSN 2278 - 0211 (Online)

\section{Violent Crisis and Economic Development in Wukari Local Government Area (LGA) of Taraba State, Nigeria}

\author{
Joshua Oji Zachariah \\ Lecturer Department of Political Science, Federal University Wukari, State, Nigeria \\ Christopher Ikem Olisah \\ Senior Lecturer, Department of Political Science, Federal University Wukari, Nigeria
}

\begin{abstract}
:
It is no longer news that the Southern part of Taraba has been bedeviled with incessant violent crises which have claimed precious lives and properties. The major aim and objectives of this study is to assess/ascertain the causes and effect of violent crisis on economic development in Wukari LGA between 2012 and 2017 and to suggest possible lasting solution to the phenomenon. The paper adopted Marxist-Pluralist theoretical framework. The study employed the instrument of questionnaire and descriptive statistical method of data analysis using SPSS Evaluation Version 15.0.The paper found that the causes of crises in various localities of Wukari LGA are multidimensional. Generally, the study noted that persistent violent crises in the area have led to reckless killings and wanton destruction of properties amounting to billions of Naira, which significantly affected socioeconomic development as well as increased the level of social-cumresidential segregation among the people. Based on the findings, this paper therefore concludes/recommended that for any meaningful development to take place in Wukari LGA, a number of policies that will check crises and address the problems of the people have to be put in place by government at all levels. These may include among others; Provision of job opportunities, establishment of skills acquisition programmes, establishment of ranches-cum-prevention of open grazing, etc. There should be ethno-religious sensitization/awareness on the need to live together and tolerant one another.
\end{abstract}

Keywords: Economic development, peaceful coexistence, tolerance, violent crisis

\section{Introduction}

The process of economic development and growth do not evolve in a vacuum. Economic choices/development, to a great extent, depends on the condition of the environment, social relations and political processes.

Despite man's efforts to develop himself and his environment, he is oftentimes faced with various forms of challenges or violent crises which tend to cripple all forms of developments and/or destroy man himself (Ajayi and Ian, 1978; Collier and Hoeffler, 1998:563-573; Richmond et al.,2010). This implies that violent crisis is inseparable from human society; it is a necessary feature of the society and is inevitable. Research revealed that any social environment characterized by stability, rule of law, and social cooperation in most cases, foster wealth creation, provide good economic opportunities and development (Fearon \& Laitin, 2003:75-90; Solimano, 2005; Onwe et al., 2015:78-86; Ray \& Esteban, 2017:263-293). However, in many societies, especially in the Third World countries like Nigeria, social relations are characterized by violent crisis which directly or indirectly impedes development processes and resulting to underdevelopment.

It is imperative to note that peaceful coexistence is conventionally viewed as core to almost (if not) all forms of positive developments in every society. Similarly, peace is traditionally seen as the absence of violent war. Therefore, this explains why almost every human society, from time immemorial desires and seeks peace as against crisis/conflict (Charles et al., 2016:21-28).The concept of peace, as defined by Roger (2006) is "the facilitation of non-exploitative, sustainable and inclusive social relationships free from direct and indirect violence and the threat of such violence". For Galtung (2011) and Charles (2016), peace is the absence of open or large-scale violence or war alongside the elimination and the proper management of factors such as abject poverty, oppression, marginalization, ignorance, etc. that causes violence or war. The authors maintained that peace is the integration of human society sustained by egalitarian oriented distribution of resources and it opposes anything that compromises basic existence and survival in the society/country. However, Richmond et al. (2010) avers that "peace is more than the absence of violence or war; it involves freedom, justice, non-crisis, conflict resolution, community building and democratization of authority". These, by implication metamorphose into sociopolitical and economic developments of individuals or group of people in a community and the country at large.

Violent crisis, in almost all cases has resulted to a lot of bloodsheds, senseless killings, destruction of property, social and economic dislocation and its attendant poverty, insecurity, unemployment, societal/human retrogression, etc. 
The economic and sociopolitical situations in any crisis zone/area have disempowered both the urban and rural poor. In line with the above, Akhakpe et al. (2012:803-819) opined that no society or nation can really boast of having achieved development if a larger percentage of its inhabitants are still wallowing under abject poverty, want and adept in socioeconomic penury. In addition, research has shown that the economic potential of crisis prone areas is not fully realized due to persistent crises. According to Mawardi (2006), most production (economic activities) in such areas is disrupted and those who attempt to establish businesses, sell products, etc. face security threats and barriers such as illegal taxes/fees imposed by some locales and/or security personnel. Similarly, day-to-day activities are interrupted, affecting daily income of individuals or households and also leading to hike in price of goods in the market resulting from imbalanced supply and demand.

It is indeed obvious that violent crisis is an aged long social phenomenon, commonly associated with the human race. Today, it is very difficult to point out to a particular society/country that has never experienced one form of violent crisis or the other. This primarily explains why the concept has attracted the attentions of various political leaders, analysts, scholars and concerned citizens.

Drawing from the above, one can aptly assert that 'peace and violent crisis are two sides of a coin'; which implies that the presence of one (say peace), is the absence of the other (say crisis) and vice-versa. This is because empirical studies have revealed that peace is a state of harmonious relationship between and among people or social groups, normal freedom from civil commotion and violence of a community, public order and serenity which propels various forms of developments in a given society; whereas violent crisis on the other hand entails a situation or an act intended to cause injuring or harm, destruction of valuable properties and/or killing human beings, resulting to all sorts of underdevelopment of a society/state. In essence, no society make any meaningful development without lasting peace; whether at individual or social group level, community or national level, powerful or weak society, etc.

According to Joshua (2013:324-339), conflict has high direct and indirect cost. In essence, violent conflict seems to be the pathway to poverty and a major challenge to the development of most countries embroiled in conflicts in Africa. He maintained that in Nigeria, various violent conflicts which the country had experienced are taking a heavy toll on the country's development. Adeyemo (2006, cited in Saheed and Egwaikhide, 2012:176-184) also buttressed that the insecurity of lives and properties which tends to prevent foreign economic relations to jumpstart the economy is one of the major implications of persistent conflicts in the land. In the same vein, Saheed and Egwaikhide (2012); Abdulbarkindo and Alupse (2015:6-68) noted that victims of violent crisis while taking refuge in refugee camps are cut off from optimal engagement in economic activities. In such condition, they cannot make meaningful contributions to the development of their respective societies, or the community where they are domiciled nor the country.

It has been observed that properties lost to various conflicts and compensations paid by various governments cannot be ploughed back to developmental objectives (Joshua, 2013:324-339). It was also noted that continued insecurity in the country has not only discouraged Transnational Corporations to invest, but has equally caused the established ones to divest by way of folding up their businesses. For Aver et al. (2013:261-266), violence is creating difficult living standards for Nigerians. He argued that violent attacks and terrorism destroy human lives, physical assets and reduce people's social relationships. This trend has created a divisible life among the people as against the hitherto mutual trust that Nigerians used to experience in the past between Muslims and Christians, as well as among the ethnic groups such as Ibo, Hausa-Fulani, Yoruba, Tiv, Nyankpa (Yeskwa), Eggon, Jukun, Igala, Idoma, Ibibio, Ijaw, Urhobo, Itsekiri, etc.

Extant literature associated various violent crises in Nigeria to varied factors, including ethno-religious intolerance. The prevalent violent crisesin, especially developing countries of Africa, Asia, and Middle-East are fueled by several factors such as ethnic chauvinism, religious bigotry, struggle for scarce natural resources, political power, psychological needs, etc. or a combination of these (Ambe-Uva, 2010; Fawole and Bello, 2011; Saheed and Egwaikhide, 2012; Nwanegbo, 2012; Egwu, 2013; Akwara \& Charles et al., 2014; Alegbeleye, 2014; Abdulbarkindo \& Alupse, 2015; Onweet al., 2015).

In his work, Charles et al. (2014) noted that no type of natural resource or primordial cleavages that do not cause crisis in Africa, especially in Nigeria. Land, water, forest, religion, ethnicity, power sharing deals in governments, revenue sharing formula, citing of local government headquarters, universities admissions space allocations, etc.; all actively cause conflicts in the continent. Examples of these are not far-fetched; the genocidal hostility between Hutus and Tutsis in Rwanda, anti-Balaka in Central African Republic, and other cases of civil wars that are ethno-religious based as in Ethiopia, Ivory Coast, Kenya, DR Congo, South Sudan, etc. In Nigeria for instance, ethno-religious crises have become a part of the national history, which has attracted intellectual investigations.

It is worthy of note that violent clashes with a colouration of ethnic and religious garb was also orchestrated under the façade of politics. This is because members of either side in a pluralist society like Nigeria will in most (if not all) cases strive to acquire or consolidate their grip or dominance over others by all means within their reach which usually results to wanton destructions and reckless killings with its consequential socio-economic backwardness.

On a general perspective, Ray and Esteban (2017:263-293) asserted that what today's violence does show, however, is that there are limits to peace and civility as long as there are enormous perceived inequities in the world; and as it is argued in this study, high on that list of perceived inequities are economic considerations. Even the most horrific conflicts, i.e. those that seem entirely motivated by religious or ethnic intolerance/hatred, have that trace of economic gain or loss that flows along with the violence, sometimes obscured/covered by the more gruesome aspects of that violence but never entirely absent. In other words, from the great religious struggles of the past to modern civil wars and ethnic conflicts, if critically observed, there is a battle for resources or economic gain such as oil, land, business opportunities, or political power, etc.; and it will interest you to know that political power is, in itself, a question of control over economic resources. 
However, this paper observed from various literatures, that there are numerous causes of violent crisis which may, or may not be the same in every society. Similarly, almost all scholars limited their works on Wukari-town and without in-depth incorporation of the people. Thus, the prima-facie of the current study is to strive to ascertain whether the crises resulted from one or more factors as well as x-ray the gravity of the crises on economic development in the contemporary Wukari LGA, through the responses of respondents.

\section{Conceptualization of Key Variables}

\subsection{Violent Crisis}

Crisis and conflict are used interchangeably in this work. The concept of violent crisis denotes the act or situation in which community/people are aggressively attacked, hurt, destroyed or killed, resulting from socio-political and/or economic problems. Alemika (2002) asserts that conflict is a product of antagonistic interests between two or more opposing forces or groups within the society. It negates peaceful coexistence as well as law and order in the society (Collier and Hoeffler, 1998). It militates against economic development and creates imbalances in social relations between conflicting parties.

According to Godwin (2006), the concept of violent crisis/conflict is "the existence of non-compatibility or disagreements between two or more actors (individuals, groups, organizations or nations) in their interaction over issues of interests, values, beliefs, emotions, goals, space, positions, scarce resources, etc. It is a situation or process in which two or more social entities are linked by at least one form of antagonistic psychological relation or interaction. The author maintained that it is a struggle over values and claims to secure status, power and resources, a struggle in which the aims of opponents are to neutralize, injure or eliminate rivals". It has also been noted that violent conflict is a situation or condition of disharmony in an interactional process. It is when two or more values, perspectives and opinions are contradictory in nature and have not been aligned or agreed upon yet (Bagaji, 2012:33-41; Alegbeleye, 2014:139-148).

However, the working definition of this study is that violent crisis is a situation in which two or more human beings (or groups) desire a goal which they perceived as being obtainable by one, but not both; and the other opponent is seen as a barrier or treat... each party mobilizes effort and apply force to obtain the goal against the other.

\subsection{Economic Development}

The concept of development is a complex and highly contested concept that does not align itself to one universally acceptable definition. In the World Development Report of 1991, the World Bank (1989) believe that the concept of development has both sociopolitical and economic attributes such as sustainable increase in living standards including consumption, education, health and environmental protection, equality of opportunity and liberties and political freedom.

Furthermore, some scholars (Todaro, 1992; Nnadozie, 2006) see development as a multi-dimensional process involving the reorganization and re-orientation of the entire economic and social system. This involves in addition to improvement of income and output, radical changes in institutional, social and administrative structures as well as in popular attitudes, customs and beliefs. In a simple term, Adeniyi (1993) defined development as a society where something moves from an unpalatable situation to palatable situation. Development also could mean the improvement in people's lifestyle through improved education, incomes, skills development and employment.

However, scholars have identified the following variables as parameters in assessing development in any given society (Rodney, 1972; World Bank, 1989; Ake, 1991; Emeh, 2013:116-128), which spread across the three broad perspectives of social, political and economic development: Good governance and political stability, low level of poverty, adequate security to protect lives and property, low rate of crimes, adequate social infrastructures, high level of industrialization, strong economy that create jobs and wealth, low unemployment rate, adequate human capital and technological knowhow, as well as increase in citizens' access to: Food, water and shelter, information and means of communication, healthcare delivery, good roads, good education, justice, etc. Whenever 80 - $95 \%$ of these variables are obtainable, there will be increase in the individual's dignity, happiness and high standard of living for the majority of the people.

These definitions by various scholars above clearly indicate that development does not have precise definition; nevertheless, the following viewpoints can be inferred as common grounds of agreement:

- That development is a process, but not static and this process are multidimensional.

- That development involves action which emphasizes the conscious efforts of the state to induce development in the society.

- It focuses on quantitative and qualitative changes in the structure, composition and performance of the forces of production.

- It also emphasized an increasing capacity to make rational value and use of natural and human resources for meeting people's social ends.

- That it ultimately brings about qualitative improvement in the standard of living of the people.

Therefore, the concept of economic development entails increases in the wealth of a society or nation through expanded production of goods and services. It includes the rise in agricultural production, manufacturing and construction as a result of the introduction of better skills/techniques and technology. Also, it includes, but not limited to increase in GDP, rise in exports, job and wealth creation, high per capita income cum high standard of living among individuals in a society. It therefore means that if the substructure is strong, there will be positive impact on the superstructure (formal and informal institutions), which to a great extent depend on the based-structure and reverse is the case when the economic structure is affected/weak. 


\section{Theoretical Framework}

\subsection{Marxist-Pluralist Theoretical Perspectives}

\subsubsection{Marxist Crisis Theory}

The Marxian school situates every social action within the ambit of substructure and lays much emphasis on historical and dialectical materialism as a methodological device (Aver et al., 2013). The theory is based upon the view that the fundamental causes of violent crisis are the social and economic forces that operates in societies.

For the Marxists, conflicts in societies emanate from the antagonistic competition for resource control among classes (i.e. the haves and the have-not) and groups in the society (Resnick and Wolff, 1978:47-57; Onimode, 1985). As noted in Akwara \& Charles (2014:121-135), social organization of the society creates classes in the society; in the process of group and class social interaction in the society, some classes and groups exclude others from holding and/or, having access to sociopolitical and economic resources of the society. This exclusion creates feelings of anger and frustration, alienation, exploitation and domination in the excluded groups and classes.

The theory further explained that these invariably lead to violent crises in the society to redress the perceived anomalies by specific and identifiable classes and or groups. This antagonistic struggle for relevance and recognition by the marginalized groups or classes will always lead to violent conflict against the group that hold and monopolizes the resources or strategic positions within or between members of the societies.

\subsubsection{Pluralist Theory}

Pluralism perspective is also used as a potent tool in explaining the dynamics in a plural society like Nigeria. The pluralists, as noted by Alegbeleye (2014) asserted that in any cultural and ethno-religious fragmented society where different groups live in close proximity, but separately from each other, inter communal relations are characterized by unchecked sociopolitical and economic competitions. It went further to explain that because the relationship between the various groups remained confined to the market place, these people failed to develop a sense of common loyalty that would overcome the cultural and ethno-religious differences among various groups within a society or between two or more societies. Unstrained socio-economic competition and fierce practice of ethnocentrism cum religion-extremism between/among different groups that follow, usually cause society to fragment against one another (Shabi and Awe, 2001; Raymond and Rajat, 2002). The plural nature of almost every part of the country, including Wukari LGA has implanted seeds of distrust, discord and the fear of domination of one ethnic or religious group over the other.

\subsubsection{Marxist-Pluralist Orientation}

These theories believed that in most cases, socioeconomic underdevelopment is not only a problem of lack of economic resources, but also largely associated with the condition of the environment as well as social relations. In other words, economic development of a given society is to a great extent determined by the social relations cum the condition of its environment. Therefore, 'Marxist-Pluralist' orientation has been devised and adopted as a potent analytical tool as well as a theoretical guide for the current study. Thus, the arguments and analysis contained in this study hinges around Marxist-Pluralist theory and will be factored in the findings.

\section{Materials and Methods}

\subsection{Study Area}

Wukari LGA lies on latitude 7051'N and longitude 9047'E which covers 4,308 $\mathrm{km}^{2}$. The local government shares borders with Benue \& Nasarawa states from the south and west, respectively. It is also closely bounded by LGAs like Donga (east), Gassol (north) and Ibi (north-west) in Taraba State (Akwara and Charles, 2014; Aremu et al., 2017:73-80).

\subsection{Sampling Area and Sample Size}

A lot of places experienced the violent crisis in Wukari local government area. However, six (6) affected villages/settlements (Abako, Chinkai, Gindin-Dorowa, Kente, Sondi and Wukari-town) were carefully selected for the purpose of this study as shown in Fig. 1. These six selected affected places constitute the sampling (focus) area. The sample size for this study is 399 . 


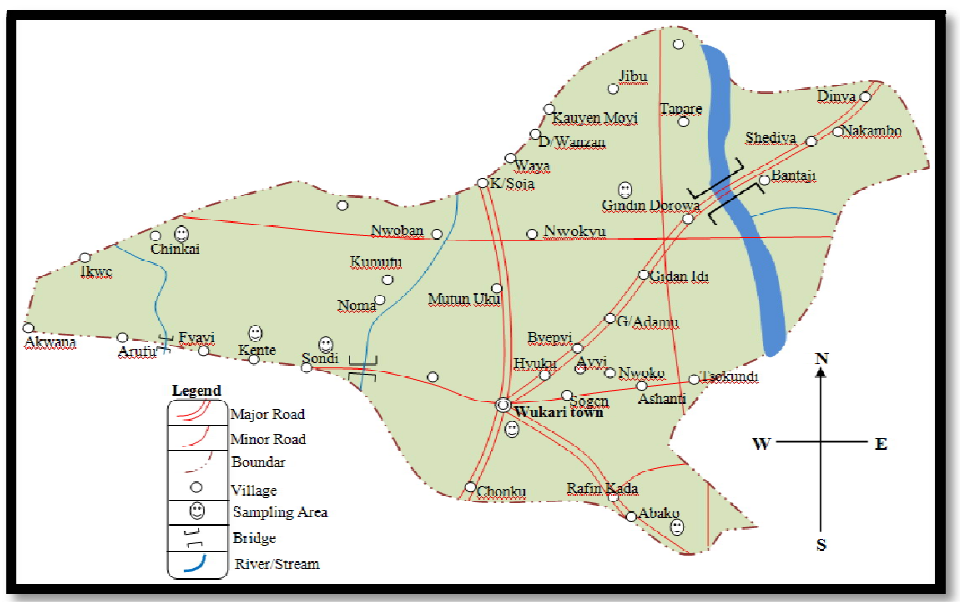

Figure 1: Map of Wukari LGA Showing Sampling Area

\begin{tabular}{|c|c|c|c|c|}
\hline S/N & Place/Town & Distributed & Retrieved (\%) & Not Returned (\%) \\
\hline 1. & Abako & 50 & $47(94 \%)$ & $3(6 \%)$ \\
\hline 2. & Chinkai & 50 & $41(82 \%)$ & $9(18 \%)$ \\
\hline 3. & Gindin-Dorowa & 50 & $39(78 \%)$ & $11(22 \%)$ \\
\hline 4. & Kente & 50 & $46(92 \%)$ & $4(8 \%)$ \\
\hline 5. & Sondi & 50 & $44(88 \%)$ & $6(12 \%)$ \\
\hline 6. & Wukari town & 149 & $138(93 \%)$ & $11(17 \%)$ \\
\hline \multicolumn{2}{|c|}{ Total } & 399 & $355(89 \%)$ & $44(11 \%)$ \\
\hline
\end{tabular}

Table 1: Distribution and Retrieval of Questionnaire

From Table 1 above, 50 copies of questionnaire were distributed to each of five (5) sampling areas while the sixth area (Wukari-town with high population density) was administered with 149 questionnaires. This implies that 44 (11\%) (i.e. error sample) of the questionnaire were either not returned or rendered invalid by the respondents. Meanwhile, 47 (94\%) questionnaires were returned from Abako, 41 (82\%) from Chnkai, 39 (78\%) from Gindin-Dorowa, 46 (92\%) from Kente, 44 (88\%) from Sondi and 138 (93\%), respectively. Thus, a total of 355 becomes the sample size for analysis in this study.

\subsection{Sampling Technique of the Study}

Considering the wideness and enormous population of Wukari LGA, it will be difficult (if not impossible) to get the view of every person living in the area. Therefore, probability sampling technique was adopted, which provided each individual of the target population with an equal opportunity to be selected and to express his/her views as contained in a structured questionnaire designed for the study.

Furthermore, a combination of Simple Random Sampling (SRS) and Stratified Sampling techniques as described by Cochran (1963) and Black \& Champion (1976) was used to approach the respondents. In line with the above, six (6) affected places from the local government were randomly selected (Fig. 1), in which both male and female respondents with certain characteristics were also randomly chosen by use of Disproportional Stratified Sampling technique.

\subsection{Source of Data Collection}

Being a field survey research, primary source of data was adopted for this study. Primary data were collected through the instrument of questionnaire to elicit information from respondents as they attempt to answer the research questions, which enable the researcher to test the research hypotheses. The primary data (result) was compared with secondary documents from published bulletins, journal articles, newspapers, etc.

\subsection{Instrument of Data Collection}

A structured questionnaire was adopted to generate data as described by Kothari and Garg (2014). The data generated was coded, analyzed and formed the basis of our analysis and findings.

\subsection{Statistical Method of Data Analysis}

For the purpose of this study, descriptive statistics was used to analyze the data generated for this research as well as drawing conclusion thereof. That is to say, simple percentage, mean, standard deviation and coefficient of variation were used for descriptive statistics. For the purpose of accurate computation, the study employed the use of SPSS version 15.0 evaluation software. 


\subsection{Validity and Reliability of the Research Instrument/Findings}

\subsubsection{Validity}

The validity of the instrument was made by experts from the Departments of Political Science, Chemical Sciences, and Sociology, Federal University Wukari. The relevant criticisms, comments and inputs from the experts were thoughtfully considered in the last edition of the instrument. The content validity was done by ensuring that the questionnaire covered all the variables of the study.

\subsubsection{Reliability}

The test-re-test reliability technique was employed in this study. Three (3) questionnaires were administered to respondents in each of the sampled areas (i.e. 3x6=18 respondents) who were not a component of the sample and data collected. Within an interval of one week, the questionnaire was re-administered to the same set of respondents and a second set of data obtained. The two sets of the data were analyzed from which a correlation coefficient value of 0.93 was obtained, indicating that the instrument is reliable.

Therefore, the measuring/testing instrument used in this study is valid and reliable; in that it measured what it was designed to measure, which reflects the views/opinions of sampled respondents. Similarly, the findings of this study are facts drawn from responses of respondents which validates and make the entire study reliable, relevant and informative.

\section{Results and Discussion}

The survey results of the study are displayed in Tables $2-9$, respectively which were generated through the instrument of questionnaire. Table 2 displayed the responses of respondents on the causes and impacts of violent crises in Abako between 2012 and 2017. From the Table, 30 (63.8\%) agreed (A) and 5 (10.6\%) strongly agreed (SA) that crises in their area emanated from intra-ethnic acrimonies. On the other hand, $10(21.3 \%)$ of the respondents disagreed (D) and $0 \%$ strongly disagreed (SD) with the statement; while $2(4.3 \%)$ were neither for nor against - i.e. undecided (U). It is imperative to note that Abako is more or less a Tiv community divided along two major dialects (Shitile and Ukum) of Tiv extraction.

However, 24 (72.3\%) disagreed and 12 (25.5\%) strongly disagreed with the statement that the crises were as a result of religion extremism/chauvinism. Meanwhile, SA \& A had 0\% while U had 2.1\% responses, respectively (Table 2). In the same vein, $29(62.7 \%)$ respondents disagreed and 11 (23.4\%) strongly disagreed with the statement that the crises were a struggle between nomadic herdsmen and farmers, and only $4.3 \%$ of the respondents agreeing to it with a mean value of 4.0426. Responses also showed that 34 (72.3\%) agreed and 2 (4.3\%) strongly agreed to the fact that there was political influence to the cause of the crises, which could be that each faction (party) to the crisis struggled to secure/protect its members/interests or seeking justice at the detriment of other opposing group members. In another aspect, 26 (55.3\%) respondents disagreed and 10 (21.3\%) strongly disagreed with the statement that the crisis was influenced by economic trading (struggle for scarce resource or market dominance), while only 5 (10.6\%) and 1 (2.1\%) strongly agreed, and then other 5 (10.7\%) responses were Undecided (Table 2). Similar, 19 (40.4\%) disagreed and 7 $(14.9 \%)$ strongly disagreed with the postulation that the crises were as a result of struggle between indigenes and settlers. Only 14 (29.8\%) agreed, which implies that it is not the real caused of the crises.

Therefore, this study revealed that Abako violent crises of $2012-2017$ can be classified as intra-ethnic crisis and the cause is said to be multi-dimensional, since it was triggered by more than one factor. That is to say, intra-ethnic acrimony with $63.8 \%$ responses, political factor (72.3\%) and indigenes-settlers struggle (29.8\%), respectively. The above argument is in line with Marxist-crisis theory which holds that there are different groups in the society with different interests. They assumed that social organization in the society creates classes, whose social interaction tend to benefit their group members at the expense of others; and where theirexistences different interests, the potentials and the likelihood of conflict is always present (Resnick and Wolff, 1978; Aver et al., 2013).

On the impacts of the crises, the result shows that the crises in Abako impacted negatively on the economic activities/production in the area which led to significant decrease in income level/spending power of the people as well as halt economic development of the area. As shown in the Table 2, 40 (85.1\%) of the respondents agreed and 6 (12.8\%) strongly agreed that the crises impacted negatively on economic production/activities in the area; while only 1 (2.1\%) disagreed. Similarly, 37 (78.7\%) agreed and 10 (21.3\%) strongly agreed that there was great decrease in income level and spending power of the locales. The study also revealed that all the 47 (100\%) respondents - i.e. 25(53.2\%) agreed and 22 $(46.8 \%)$ strongly agreed that there was significant decrease in economic development in the area as a result ofthe violent crises. And owing to the fact that the substructure (economic based) was affected by the crises, 38 (80.9\%) strongly agreed and $9(19.1 \%)$ agreed that other social aspects of the people were significantly affected as well (Table 2). On the other hand, responses regarding statements on serial numbers 7, 9 and 11 of the Table depict that only 1 (2.1\%) agreed to each of these statements while about $98 \%$ disagreed; which implies that crises impacted negatively on both the people and socioeconomic development of the community. This result and the above argument corroborate with the reports of different scholars who adduced that no meaningful or sustainable development will take place when there are no enabling environments; and that conflicts significantly resulted to low provision and sustainability of infrastructure facilities in crises atmosphere (Collier \& Hoeffler, 1998; Ali et al., 2014; Onwe et al., 2015). Similarly, Aver et al. (2013),Akwara \& Charles (2014) reported that violent crisisoften creates difficult living standards for the locales which pave way for poverty to creep in; and poverty in turn causes anger, frustration and deprivations which further fuels the crises and turns the crises into perpetual cycles. 


\begin{tabular}{|c|c|c|c|c|c|c|c|c|c|c|}
\hline $\mathrm{S} / \mathrm{N}$ & Statement & $\begin{array}{c}\text { SA } \\
(\%)\end{array}$ & $\begin{array}{c}A \\
(\%)\end{array}$ & $\begin{array}{c}U \\
(\%)\end{array}$ & $\begin{array}{c}\text { D } \\
(\%)\end{array}$ & $\begin{array}{c}\text { SD } \\
(\%)\end{array}$ & Total & Mean & St.D & $\mathrm{CV}$ \\
\hline 1. & $\begin{array}{c}\text { The recent violent } \\
\text { crisis (2012- } \\
\text { 2017) in your } \\
\text { locality was } \\
\text { influenced by } \\
\text { ethnicity } \\
\text { (intra/inter). }\end{array}$ & $\begin{array}{c}5 \\
(10.6)\end{array}$ & $\begin{array}{c}30 \\
(63.8)\end{array}$ & $\begin{array}{c}2 \\
(4.3)\end{array}$ & $\begin{array}{c}10 \\
(21.3)\end{array}$ & $\begin{array}{c}0 \\
(0.0)\end{array}$ & $\begin{array}{c}47 \\
(100)\end{array}$ & 2.3617 & .94237 & .888 \\
\hline 2. & $\begin{array}{c}\text { The violent crisis } \\
\text { in your locality } \\
\text { was caused by } \\
\text { religious } \\
\text { extremism. }\end{array}$ & $\begin{array}{c}0 \\
(0.0)\end{array}$ & $\begin{array}{c}0 \\
(0.0)\end{array}$ & $\begin{array}{c}1 \\
(2.1)\end{array}$ & $\begin{array}{c}34 \\
(72.3)\end{array}$ & $\begin{array}{c}12 \\
(25.5)\end{array}$ & $\begin{array}{c}47 \\
(100)\end{array}$ & 4.2340 & .47607 & .227 \\
\hline 3. & $\begin{array}{c}\text { The violent crisis } \\
\text { in your locality } \\
\text { was caused by the } \\
\text { struggle between } \\
\text { nomadic } \\
\text { herdsmen and } \\
\text { farmers. }\end{array}$ & $\begin{array}{c}0 \\
(0.0)\end{array}$ & $\begin{array}{c}2 \\
(4.3)\end{array}$ & $\begin{array}{c}5 \\
(10.6)\end{array}$ & $\begin{array}{c}29 \\
(61.7)\end{array}$ & $\begin{array}{c}11 \\
(23.4)\end{array}$ & $\begin{array}{c}47 \\
(100)\end{array}$ & 4.0426 & .72103 & .520 \\
\hline 4. & $\begin{array}{l}\text { The violent crisis } \\
\text { in your locality } \\
\text { was politically } \\
\text { influenced. }\end{array}$ & $\begin{array}{c}2 \\
(4.3)\end{array}$ & $\begin{array}{c}34 \\
(72.3)\end{array}$ & $\begin{array}{c}7 \\
(14.9)\end{array}$ & $\begin{array}{c}4 \\
(8.5)\end{array}$ & $\begin{array}{c}0 \\
(0.0)\end{array}$ & $\begin{array}{c}47 \\
(100)\end{array}$ & 2.2766 & .68214 & .465 \\
\hline 5. & $\begin{array}{l}\text { The crisis in your } \\
\text { locality was } \\
\text { influenced by } \\
\text { economic trading } \\
\text { (struggle for } \\
\text { scarce resource or } \\
\text { market } \\
\text { dominance). }\end{array}$ & $\begin{array}{c}1 \\
(2.1)\end{array}$ & $\begin{array}{c}5 \\
(10.6)\end{array}$ & $\begin{array}{c}5 \\
(10.6)\end{array}$ & $\begin{array}{c}26 \\
(55.3)\end{array}$ & $\begin{array}{c}10 \\
(21.3)\end{array}$ & $\begin{array}{c}47 \\
(100)\end{array}$ & 3.8298 & .96277 & .927 \\
\hline 6. & $\begin{array}{l}\text { The crisis in your } \\
\text { locality was as a } \\
\text { result of struggle } \\
\text { between indigenes } \\
\text { \& settlers }\end{array}$ & $\begin{array}{c}0 \\
(0.0)\end{array}$ & $\begin{array}{c}14 \\
(29.8)\end{array}$ & $\begin{array}{c}7 \\
(14.9)\end{array}$ & $\begin{array}{c}19 \\
(40.4)\end{array}$ & $\begin{array}{c}7 \\
(14.9)\end{array}$ & $\begin{array}{c}47 \\
(100)\end{array}$ & 3.4468 & 1.05930 & $\begin{array}{c}1.12 \\
2\end{array}$ \\
\hline 7. & $\begin{array}{l}\text { The recent violent } \\
\text { crisis of 2012- } \\
2017 \text { impacted, } \\
\text { positively on the } \\
\text { economic } \\
\text { activities/producti } \\
\text { on in the study } \\
\text { area. }\end{array}$ & $\begin{array}{c}1 \\
(2.1)\end{array}$ & $\begin{array}{c}0 \\
(0.0)\end{array}$ & $\begin{array}{c}0 \\
(0.0)\end{array}$ & $\begin{array}{c}27 \\
(57.4)\end{array}$ & $\begin{array}{c}19 \\
(40.4)\end{array}$ & $\begin{array}{c}47 \\
(100)\end{array}$ & 4.3404 & .70020 & .490 \\
\hline 8. & $\begin{array}{l}\text { The recent violent } \\
\text { crisis of 2012- } \\
2017 \text { impacted, } \\
\text { negatively on the } \\
\text { economic } \\
\text { activities/producti } \\
\text { on in the study } \\
\text { area. }\end{array}$ & $\begin{array}{c}6 \\
(12.8)\end{array}$ & $\begin{array}{c}40 \\
(85.1)\end{array}$ & $\begin{array}{c}0 \\
(0.0)\end{array}$ & $\begin{array}{c}1 \\
(2.1)\end{array}$ & $\begin{array}{c}0 \\
0.0)\end{array}$ & $\begin{array}{c}47 \\
(100)\end{array}$ & 1.9149 & .45825 & .210 \\
\hline 9. & $\begin{array}{l}\text { As a result of the } \\
\text { recent violent } \\
\text { crisis in your } \\
\text { locality, there was } \\
\text { great increase in } \\
\text { income level and } \\
\text { spending power of } \\
\text { the locales. }\end{array}$ & $\begin{array}{c}0 \\
(0.0)\end{array}$ & $\begin{array}{c}1 \\
(2.1)\end{array}$ & $\begin{array}{c}0 \\
(0.0)\end{array}$ & $\begin{array}{c}39 \\
(83.0)\end{array}$ & $\begin{array}{c}7 \\
(14.9)\end{array}$ & $\begin{array}{c}47 \\
(100)\end{array}$ & 4.1064 & .47704 & .228 \\
\hline 10. & $\begin{array}{l}\text { As a result of the } \\
\text { recent violent } \\
\text { crisis in your } \\
\text { locality, there was } \\
\text { great decrease in } \\
\text { income level and } \\
\text { spending power of } \\
\text { the locales. }\end{array}$ & $\begin{array}{c}10 \\
(21.3)\end{array}$ & $\begin{array}{c}37 \\
(78.7)\end{array}$ & $\begin{array}{c}0 \\
(0.0)\end{array}$ & $\begin{array}{c}0 \\
(0.0)\end{array}$ & $\begin{array}{c}0 \\
(0.0)\end{array}$ & $\begin{array}{c}47 \\
(100)\end{array}$ & 1.7872 & .41369 & .171 \\
\hline
\end{tabular}




\begin{tabular}{|c|c|c|c|c|c|c|c|c|c|c|}
\hline S/N & Statement & $\begin{array}{c}\text { SA } \\
(\%)\end{array}$ & $\begin{array}{c}A \\
(\%)\end{array}$ & $\begin{array}{c}U \\
(\%)\end{array}$ & $\begin{array}{c}D \\
(\%)\end{array}$ & $\begin{array}{c}\text { SD } \\
(\%)\end{array}$ & Total & Mean & St.D & $\mathrm{CV}$ \\
\hline 11. & $\begin{array}{l}\text { Due to the recent } \\
\text { violent crisis, } \\
\text { there was } \\
\text { significant } \\
\text { increase in } \\
\text { economic } \\
\text { development in } \\
\text { the study area. }\end{array}$ & $\begin{array}{c}0 \\
(0.0)\end{array}$ & $\begin{array}{c}1 \\
(2.1)\end{array}$ & $\begin{array}{c}4 \\
(8.5)\end{array}$ & $\begin{array}{c}32 \\
(68.1)\end{array}$ & $\begin{array}{c}10 \\
(21.3)\end{array}$ & $\begin{array}{c}47 \\
(100)\end{array}$ & 4.0851 & .61960 & .384 \\
\hline 12. & $\begin{array}{l}\text { Due to the recent } \\
\text { violent crisis, } \\
\text { there was } \\
\text { significant } \\
\text { decrease in } \\
\text { economic } \\
\text { development in } \\
\text { the study area. }\end{array}$ & $\begin{array}{c}22 \\
(46.8)\end{array}$ & $\begin{array}{c}25 \\
53.2)\end{array}$ & $\begin{array}{c}0 \\
(0.0)\end{array}$ & $\begin{array}{c}0 \\
(0.0)\end{array}$ & $\begin{array}{c}0 \\
(0.0)\end{array}$ & $\begin{array}{c}47 \\
(100)\end{array}$ & 1.5319 & .50437 & .254 \\
\hline 13. & $\begin{array}{l}\text { And because the } \\
\text { substructure } \\
\text { (economic) was } \\
\text { affected by the } \\
\text { crises, other social } \\
\text { aspects of the } \\
\text { people were also } \\
\text { affected. }\end{array}$ & $\begin{array}{c}38 \\
(80.9)\end{array}$ & $\begin{array}{c}9 \\
(19.1)\end{array}$ & $\begin{array}{c}0 \\
(0.0)\end{array}$ & $\begin{array}{c}0 \\
(0.0)\end{array}$ & $\begin{array}{c}0 \\
(0.0)\end{array}$ & $\begin{array}{c}47 \\
(100)\end{array}$ & 1.1915 & .39773 & .158 \\
\hline
\end{tabular}

Table 2: Responses of Respondents on the Causes and Impacts of Violent Crisis in

Abako between 2012 and 2017

Source: Field Survey (2018)

$S A=$ Strongly Agree, $A=$ Agree U = Undecided, $D=$ Disagree, $S D=$ Strongly Disagree,

ST.D = Standard Deviation, $C V=$ Coefficient of Variation

\begin{tabular}{|c|c|c|c|c|c|c|c|c|c|c|}
\hline $\mathbf{S} / \mathbf{N}$ & Statement & $\begin{array}{c}\text { SA } \\
(\%)\end{array}$ & $\begin{array}{c}A \\
(\%)\end{array}$ & $\begin{array}{c}U \\
(\%)\end{array}$ & $\begin{array}{c} \\
(\%)\end{array}$ & $\begin{array}{c}\text { SD } \\
(\%)\end{array}$ & Total & Mean & St.D & $\mathrm{CV}$ \\
\hline 1. & $\begin{array}{c}\text { The recent violent } \\
\text { crisis (2012-2017) } \\
\text { in your locality } \\
\text { was influenced by } \\
\text { ethnicity } \\
\text { (intra/inter). }\end{array}$ & $\begin{array}{c}3 \\
(7.3)\end{array}$ & $\begin{array}{c}8 \\
(19.5)\end{array}$ & $\begin{array}{c}4 \\
(9.8)\end{array}$ & $\begin{array}{c}19 \\
(46.3)\end{array}$ & $\begin{array}{c}7 \\
(17.1)\end{array}$ & $\begin{array}{c}41 \\
(100)\end{array}$ & 3.4634 & 1.20618 & 1.455 \\
\hline 2. & $\begin{array}{l}\text { The violent crisis } \\
\text { in your locality } \\
\text { was caused by } \\
\text { religious } \\
\text { extremism. }\end{array}$ & $\begin{array}{c}20 \\
(48.8)\end{array}$ & $\begin{array}{c}21 \\
(51.2)\end{array}$ & $\begin{array}{c}0 \\
(0.0)\end{array}$ & $\begin{array}{c}0 \\
(0.0)\end{array}$ & $\begin{array}{c}0 \\
(0.0)\end{array}$ & $\begin{array}{c}41 \\
(100)\end{array}$ & 1.5122 & .50606 & .256 \\
\hline 3. & $\begin{array}{l}\text { The violent crisis } \\
\text { in your locality } \\
\text { was caused by the } \\
\text { struggle between } \\
\text { nomadic herdsmen } \\
\text { and farmers. }\end{array}$ & $\begin{array}{c}28 \\
(68.3)\end{array}$ & $\begin{array}{c}10 \\
(24.4)\end{array}$ & $\begin{array}{c}2 \\
(4.9)\end{array}$ & $\begin{array}{c}1 \\
(2.4)\end{array}$ & $\begin{array}{c}0 \\
(0.0)\end{array}$ & $\begin{array}{c}41 \\
(100)\end{array}$ & 1.4146 & .70624 & .499 \\
\hline 4. & $\begin{array}{l}\text { The violent crisis } \\
\text { in your locality } \\
\text { was politically } \\
\text { influenced. }\end{array}$ & $\begin{array}{c}4 \\
(9.8)\end{array}$ & $\begin{array}{c}25 \\
(61.0)\end{array}$ & $\begin{array}{c}6 \\
(14.6)\end{array}$ & $\begin{array}{c}6 \\
(14.6)\end{array}$ & $\begin{array}{c}0 \\
(0.0)\end{array}$ & $\begin{array}{c}41 \\
(100)\end{array}$ & 2.3415 & .85469 & .730 \\
\hline 5. & $\begin{array}{l}\text { The crisis in your } \\
\text { locality was } \\
\text { influenced by } \\
\text { economic trading } \\
\text { (struggle for scarce } \\
\text { resource or market } \\
\text { dominance). }\end{array}$ & $\begin{array}{c}2 \\
(4.9)\end{array}$ & $\begin{array}{c}5 \\
(12.2)\end{array}$ & $\begin{array}{c}6 \\
(14.6)\end{array}$ & $\begin{array}{c}22 \\
(53.7)\end{array}$ & $\begin{array}{c}6 \\
(14.6)\end{array}$ & $\begin{array}{c}41 \\
(100)\end{array}$ & 3.6098 & 1.04590 & 1.094 \\
\hline 6. & $\begin{array}{l}\text { The crisis in your } \\
\text { locality was as a } \\
\text { result of struggle } \\
\text { between indigenes } \\
\& \text { settlers }\end{array}$ & $\begin{array}{c}3 \\
(7.3)\end{array}$ & $\begin{array}{c}22 \\
(53.7)\end{array}$ & $\begin{array}{c}2 \\
(4.9)\end{array}$ & $\begin{array}{c}12 \\
(19.3)\end{array}$ & $\begin{array}{c}2 \\
(4.90)\end{array}$ & $\begin{array}{c}41 \\
(100)\end{array}$ & 2.7073 & 1.12347 & 1.262 \\
\hline
\end{tabular}




\begin{tabular}{|c|c|c|c|c|c|c|c|c|c|c|}
\hline $\mathrm{S} / \mathrm{N}$ & Statement & $\begin{array}{c}\text { SA } \\
(\%)\end{array}$ & $\begin{array}{c}A \\
(\%)\end{array}$ & $\begin{array}{c}U \\
(\%)\end{array}$ & $\begin{array}{c} \\
(\%)\end{array}$ & $\begin{array}{c}\text { SD } \\
(\%)\end{array}$ & Total & Mean & St.D & $\mathbf{C V}$ \\
\hline 7. & $\begin{array}{l}\text { The recent violent } \\
\text { crisis of 2012- } \\
2017 \text { impacted, } \\
\text { positively on the } \\
\text { economic } \\
\text { activities/producti } \\
\text { on in the study } \\
\text { area. }\end{array}$ & $\begin{array}{c}0 \\
(0.0)\end{array}$ & $\begin{array}{c}2 \\
(4.9)\end{array}$ & $\begin{array}{c}2 \\
(4.9)\end{array}$ & $\begin{array}{c}20 \\
(48.8)\end{array}$ & $\begin{array}{c}17 \\
(41.5)\end{array}$ & $\begin{array}{c}41 \\
(100)\end{array}$ & 4.2683 & .77538 & .601 \\
\hline 8. & $\begin{array}{l}\text { The recent violent } \\
\text { crisis of 2012- } \\
2017 \text { impacted, } \\
\text { negatively on the } \\
\text { economic } \\
\text { activities/producti } \\
\text { on in the study } \\
\text { area. }\end{array}$ & $\begin{array}{c}10 \\
(24.4)\end{array}$ & $\begin{array}{c}30 \\
(73.2)\end{array}$ & $\begin{array}{c}1 \\
(2.4)\end{array}$ & $\begin{array}{c}0 \\
(0.0)\end{array}$ & $\begin{array}{c}0 \\
(0.0)\end{array}$ & $\begin{array}{c}41 \\
(100)\end{array}$ & 1.7805 & .47498 & .226 \\
\hline 9. & $\begin{array}{l}\text { As a result of the } \\
\text { recent violent } \\
\text { crisis in your } \\
\text { locality, there was } \\
\text { great increase in } \\
\text { income level and } \\
\text { spending power of } \\
\text { the locales. }\end{array}$ & $\begin{array}{c}0 \\
(0.0)\end{array}$ & $\begin{array}{c}0 \\
(0.0)\end{array}$ & $\begin{array}{c}3 \\
(7.3)\end{array}$ & $\begin{array}{c}29 \\
(70.7)\end{array}$ & $\begin{array}{c}9 \\
(22.0)\end{array}$ & $\begin{array}{c}41 \\
(100)\end{array}$ & 4.1463 & .52730 & .278 \\
\hline 10. & $\begin{array}{l}\text { As a result of the } \\
\text { recent violent } \\
\text { crisis in your } \\
\text { locality, there was } \\
\text { great decrease in } \\
\text { income level and } \\
\text { spending power of } \\
\text { the locales. }\end{array}$ & $\begin{array}{c}22 \\
(53.7)\end{array}$ & $\begin{array}{c}18 \\
(43.9)\end{array}$ & $\begin{array}{c}1 \\
(2.4)\end{array}$ & $\begin{array}{c}0 \\
(0.0)\end{array}$ & $\begin{array}{c}0 \\
(0.0)\end{array}$ & $\begin{array}{c}41 \\
(100)\end{array}$ & 1.4878 & .55326 & .306 \\
\hline 11. & $\begin{array}{l}\text { Due to the recent } \\
\text { violent crisis, there } \\
\text { was significant } \\
\text { increase in } \\
\text { economic } \\
\text { development in the } \\
\text { study area. }\end{array}$ & $\begin{array}{c}0 \\
(0.0)\end{array}$ & $\begin{array}{c}0 \\
(0.0)\end{array}$ & $\begin{array}{c}5 \\
(12.2)\end{array}$ & $\begin{array}{c}26 \\
(63.4)\end{array}$ & $\begin{array}{c}10 \\
(24.4)\end{array}$ & $\begin{array}{c}41 \\
(100)\end{array}$ & 4.1220 & .59980 & .360 \\
\hline 12. & $\begin{array}{l}\text { Due to the recent } \\
\text { violent crisis, there } \\
\text { was significant } \\
\text { decrease in } \\
\text { economic } \\
\text { development in the } \\
\text { study area. }\end{array}$ & $\begin{array}{c}21 \\
(51.2)\end{array}$ & $\begin{array}{c}20 \\
(48.8)\end{array}$ & $\begin{array}{c}0 \\
(0.0)\end{array}$ & $\begin{array}{c}0 \\
(0.0)\end{array}$ & $\begin{array}{c}0 \\
(0.0)\end{array}$ & $\begin{array}{c}41 \\
(100)\end{array}$ & 1.4878 & .50606 & .256 \\
\hline 13. & $\begin{array}{l}\text { And because the } \\
\text { substructure } \\
\text { (economic) was } \\
\text { affected by the } \\
\text { crises, other social } \\
\text { aspects of the } \\
\text { people were also } \\
\text { affected. }\end{array}$ & $\begin{array}{c}33 \\
(80.5)\end{array}$ & $\begin{array}{c}6 \\
(14.6)\end{array}$ & $\begin{array}{c}1 \\
(2.4)\end{array}$ & $\begin{array}{c}1 \\
(2.4)\end{array}$ & $\begin{array}{c}0 \\
(0.0)\end{array}$ & $\begin{array}{c}41 \\
(100)\end{array}$ & 1.2927 & .74980 & .562 \\
\hline
\end{tabular}

Table 3: Responses of Respondents on the Causes and Impacts of Violent Crisis in Chinkai between 2012 and 2017 Source: Field Survey (2018)

$S A=$ Strongly Agree, $A=$ Agree, $U=$ Undecided, $D=$ Disagree, $S D=$ Strongly Disagree, St. $D=$ Standard Deviation, $C V=$ Coefficient of Variation

The responses of respondents on the causes and impacts of violent crises in Chinkai (2012 - 2017) were well presented in Table 3. The result indicated that crises in Chinkai were influenced by several factors which include religious extremism or intolerance, nomadic herders-farmers phenomenon, political factor and indigenes-settlers struggle of which religious chauvinism topped the list with $100 \%$ (i.e. 48.8\% Strongly Agreed and 51.2\% Agreed), while herders-farmers struggle has $93.7 \%(68.3 \% \mathrm{SA}$ and $24.4 \% \mathrm{~A})$ followed by political factor with $70.8 \%(61.0 \% \mathrm{~A}$ and $9.8 \% \mathrm{SA})$ and indigenessettlers with $61.0 \%$ (53.7\% A and $7.3 \% \mathrm{SA}$ ) as disclosed in Table 3. Thus, it can be observed from the responses on the causes of crisis in Chinkai to be more complex as compare to those of Abako community where intra-ethnic and group interest (political) take precedence. The causes of crisis in Chinkai can best be explained within the purview of Pluralist 
perspective of conflict in the society as noted in the theoretical framework of this study. This school of thought postulates that in any cultural and ethno-religious fragmented society where different groups live in close proximity but separately from each other, inter communal relations are characterized by unchecked sociopolitical and economic competitions (Raymond and Rajat, 2002; Alegbeleye, 2014). They stressed that unstrained socio-economic competition and fierce practice of ethnocentrism cum religion-extremism between/among different groups that follow, usually cause society to antagonistically fragment against one another. Therefore, the end-product of such hostile fragmentation is violent crisis with consequential effects on the social wellbeing of the inhabitants and overall infrastructural cum economic development of the society as revealed in this study.

Meanwhile, $63.4 \%$ and $68.3 \%$ respondents disagreed with the statements on serial numbers 1 and 5 of the Table which implies that the crises in Chinkai were not influenced by ethnicity nor struggle for market or trading dominance.

Commenting on the impact of the crises in Chinkai, only 2 (4.9\%) of the 41 respondents agreed that the crises impacted positively on economic production of the area, while $90 \%$ (i.e. $48.8 \%$ D and $41.5 \%$ SD) vehemently disagreed (Table 3). On the other hand, $97.6 \%$ of the respondents agreed that the crises in Chinkai impacted negatively on economic activities/production and greatly decreased income level and spending power of the people while 100\% (51.2\% SA and $48.8 \% \mathrm{~A}$ ) of the respondents agreed to the fact that there was significant decrease in economic development in the area due to devastated effect of the crises. Similarly, $95.2 \%$ strongly agreed that other aspects of social life of the area were also affected (Table 3). This shows that the impact of crisis in Chinkai is comparatively alike with those of Abako as earlier noted.

This result also agreed with various literature on the effects of violent crisis in every human society. It has been reported by many researchersthat even though some few people do gain from crisis situation; in most cases, violent crises often take diverse hostile dimensions which usually leave tales of woes, destruction of properties worth millions of naira, reckless killing of innocent lives and economic downturn in the affected society,as the case with the current study area (Adebayo, 2010; Saheed \& Egwaikhide, 2012; Nwanegbo, 2012; Aver et al., 2013; Alegbeleye, 2014; Akwara \& Charles, 2014; Onwe et al., 2015).

The responses of the respondents on the causes and effectsof crisis in Gindin-Dorowa are as presented in Table 4.It indicates that religious intolerance between the two major religions (Christianity and Islam) was the central factor and was linked to nomadic herdsmen-farmers phenomenon, followed by direct or indirect influence of politics. From the Table, all the $39(100 \%)$ respondents ascribed that religious bigotry created animosity alongside suspicious feelings among the people which greatly inflamed the crises while $77 \%$ (46.2\% A and 30.8\% SA) of the total respondents said that the crisis was also cause by the struggle between nomadic herdsmen and farmers. In fact, interaction with some of the respondents for the purpose of this research revealed that the clash between herdsmen and farmers was "the last struck that broke the camel's back" in Gindin-Dorowa. Similarly, 53.8\% stated that there was political undertone/trace to the crises outbreak.

Responding on whether the violent crisis of 2012-2017 impacted positively on the economic production in Gindin-Dorowa, the result revealed that SA and A recorded $0.0 \%$ and $2.6 \%$ with U recording $7.7 \%$ while D and SD recorded $43.6 \%$ and $46.2 \%$, respectively (Table 4 ), which implied that reverse was the case. In other words, respondents disagreed with the statement that the violent crises impacted positively on the economic production in the area. On the contrary, all the $39(66.7 \% \mathrm{~A}$ and $33.3 \% \mathrm{SA})$ respondents agreed that the violent crisis impacted negatively on the economic production in Gindin-Dorowa. Also, more than $80 \%$ of the respondents disagreed with the statements that there was great increase in income level and spending power of the locales as well as economic development in the area. Needless to say, the respondents massively (97.8\%) agreed that there was great decrease in income level and spending power of the people as well as economic development in the area due to the devastated impact of the crises.

However, the inhabitants of the area generally affirmed that the violent crises claimed many lives and properties worth thousands of naira. They also said that as a result of the crises, many people have fled the area haven lose their loves ones, homes, means of livelihood, etc. Thus, these findings corroborate what other authors have report elsewhere on the implication of violent conflict. For instance, Collier \& Hoeffler (1998:563-573) and Fearon \& Laitin (2003:75-90) asserted that per capita income and conflict are significantly and negatively correlated. In the like manner, Akwara and Charles (2014:121-135) succinctly buttressed that conflict sends so many people fleeing from their homes and/or loss of material possessions. And some occasions, survivors flee from the areas never to return again while some others come back to start life all over again having lost all their life-longhard earned possessions. Saheed and Egwaikhide (2012:176-184) also noted that insecurity of lives and properties tends to prevent both local and foreign investments as well as economic relations to jumpstart the economy, which without doubt, has been the major implication of persistent conflicts in the society. 


\begin{tabular}{|c|c|c|c|c|c|c|c|c|c|c|}
\hline $\mathbf{S} / \mathbf{N}$ & Statement & $\begin{array}{c}\text { SA } \\
(\%)\end{array}$ & $\begin{array}{c}A \\
(\%)\end{array}$ & $\begin{array}{c}U \\
(\%)\end{array}$ & $\begin{array}{c}D \\
(\%)\end{array}$ & $\begin{array}{c}\text { SD } \\
(\%)\end{array}$ & Total & Mean & St.D & CV\% \\
\hline 1. & $\begin{array}{c}\text { The recent violent } \\
\text { crisis (2012-2017) } \\
\text { in your locality was } \\
\text { influenced by } \\
\text { ethnicity } \\
\text { (intra/inter). }\end{array}$ & $\begin{array}{c}0 \\
(0.0)\end{array}$ & $\begin{array}{c}6 \\
(15.4)\end{array}$ & $\begin{array}{c}0 \\
(0.0)\end{array}$ & $\begin{array}{c}27 \\
(69.2)\end{array}$ & $\begin{array}{c}6 \\
(15.4)\end{array}$ & $\begin{array}{c}39 \\
(100)\end{array}$ & 3.8462 & .87475 & .765 \\
\hline 2. & $\begin{array}{c}\text { The violent crisis in } \\
\text { your locality was } \\
\text { caused by religious } \\
\text { extremism. }\end{array}$ & $\begin{array}{c}30 \\
(76.9)\end{array}$ & $\begin{array}{c}9 \\
(23.1)\end{array}$ & $\begin{array}{c}0 \\
(0.0)\end{array}$ & $\begin{array}{c}0 \\
(0.0)\end{array}$ & $\begin{array}{c}0 \\
(0.0)\end{array}$ & $\begin{array}{c}39 \\
(100)\end{array}$ & 1.2308 & .42683 & .182 \\
\hline 3. & $\begin{array}{l}\text { The violent crisis in } \\
\text { your locality was } \\
\text { caused by the } \\
\text { struggle between } \\
\text { nomadic herdsmen } \\
\text { and farmers. }\end{array}$ & $\begin{array}{c}12 \\
(30.8)\end{array}$ & $\begin{array}{c}18 \\
(46.2)\end{array}$ & $\begin{array}{c}4 \\
(10.3)\end{array}$ & $\begin{array}{c}0 \\
(0.0)\end{array}$ & $\begin{array}{c}5 \\
(12.8)\end{array}$ & $\begin{array}{c}39 \\
(100)\end{array}$ & 2.1795 & $\begin{array}{c}1.2538 \\
7\end{array}$ & 1.572 \\
\hline 4. & $\begin{array}{c}\text { The violent crisis in } \\
\text { your locality was } \\
\text { politically } \\
\text { influenced. }\end{array}$ & $\begin{array}{c}6 \\
(15.4)\end{array}$ & $\begin{array}{c}15 \\
(38.5)\end{array}$ & $\begin{array}{c}12 \\
(30.8)\end{array}$ & $\begin{array}{c}2 \\
(5.1)\end{array}$ & $\begin{array}{c}4 \\
(10.3)\end{array}$ & $\begin{array}{c}39 \\
(100)\end{array}$ & 2.5641 & $\begin{array}{c}1.1423 \\
6\end{array}$ & 1.305 \\
\hline 5. & $\begin{array}{l}\text { The crisis in your } \\
\text { locality was } \\
\text { influenced by } \\
\text { economic trading } \\
\text { (struggle for scarce } \\
\text { resource or market } \\
\text { dominance). }\end{array}$ & $\begin{array}{c}0 \\
(0.0)\end{array}$ & $\begin{array}{c}0 \\
(0.0)\end{array}$ & $\begin{array}{c}11 \\
(28.2)\end{array}$ & $\begin{array}{c}15 \\
(38.5)\end{array}$ & $\begin{array}{c}13 \\
(33.3)\end{array}$ & $\begin{array}{c}39 \\
(100)\end{array}$ & 4.0513 & .79302 & .629 \\
\hline 6. & $\begin{array}{l}\text { The crisis in your } \\
\text { locality was as a } \\
\text { result of struggle } \\
\text { between indigenes } \\
\text { \& settlers }\end{array}$ & $\begin{array}{c}0 \\
(0.0)\end{array}$ & $\begin{array}{c}5 \\
(12.8)\end{array}$ & $\begin{array}{c}5 \\
(12.8)\end{array}$ & $\begin{array}{c}14 \\
(35.9)\end{array}$ & $\begin{array}{c}15 \\
(38.5)\end{array}$ & $\begin{array}{c}39 \\
(100)\end{array}$ & 4.0000 & $\begin{array}{c}1.0259 \\
8\end{array}$ & 1.053 \\
\hline 7. & $\begin{array}{l}\text { The recent violent } \\
\text { crisis of } 2012-2017 \\
\text { impacted, positively } \\
\text { on the economic } \\
\text { activities/productio } \\
\mathrm{n} \text { in the study area. }\end{array}$ & $\begin{array}{c}0 \\
(0.0)\end{array}$ & $\begin{array}{c}1 \\
(2.6)\end{array}$ & $\begin{array}{c}3 \\
(7.7)\end{array}$ & $\begin{array}{c}17 \\
(43.6)\end{array}$ & $\begin{array}{c}18 \\
(46.2)\end{array}$ & $\begin{array}{c}39 \\
(100)\end{array}$ & 4.3333 & .73747 & .544 \\
\hline 8. & $\begin{array}{l}\text { The recent violent } \\
\text { crisis of 2012-2017 } \\
\text { impacted, negatively } \\
\text { on the economic } \\
\text { activities/productio } \\
\mathrm{n} \text { in the study area. }\end{array}$ & $\begin{array}{c}13 \\
(33.3)\end{array}$ & $\begin{array}{c}26 \\
(66.7)\end{array}$ & $\begin{array}{c}0 \\
(0.0)\end{array}$ & $\begin{array}{c}0 \\
(0.0)\end{array}$ & $\begin{array}{c}0 \\
(0.0)\end{array}$ & $\begin{array}{c}39 \\
(100)\end{array}$ & 1.6667 & .47757 & .228 \\
\hline 9. & $\begin{array}{l}\text { As a result of the } \\
\text { recent violent crisis } \\
\text { in your locality, } \\
\text { there was great } \\
\text { increase in income } \\
\text { level and spending } \\
\text { power of the } \\
\text { locales. }\end{array}$ & $\begin{array}{c}0 \\
(0.0)\end{array}$ & $\begin{array}{c}2 \\
(5.1)\end{array}$ & $\begin{array}{c}3 \\
(7.7)\end{array}$ & $\begin{array}{c}24 \\
(61.5)\end{array}$ & $\begin{array}{c}10 \\
(25.6)\end{array}$ & $\begin{array}{c}39 \\
(100)\end{array}$ & 4.1282 & .73196 & .536 \\
\hline 10. & $\begin{array}{l}\text { As a result of the } \\
\text { recent violent crisis } \\
\text { in your locality, } \\
\text { there was great } \\
\text { decrease in income } \\
\text { level and spending } \\
\text { power of the } \\
\text { locales. }\end{array}$ & $\begin{array}{c}18 \\
(46.2)\end{array}$ & $\begin{array}{c}20 \\
(51.3)\end{array}$ & $\begin{array}{c}1 \\
(2.6)\end{array}$ & $\begin{array}{c}0 \\
(0.0)\end{array}$ & $\begin{array}{c}0 \\
(0.0)\end{array}$ & $\begin{array}{c}39 \\
(100)\end{array}$ & 1.5641 & .55226 & .305 \\
\hline 11. & $\begin{array}{l}\text { Due to the recent } \\
\text { violent crisis, there } \\
\text { was significant } \\
\text { increase in } \\
\text { economic } \\
\text { development in the } \\
\text { study area. }\end{array}$ & $\begin{array}{c}0 \\
(0.0)\end{array}$ & $\begin{array}{c}1 \\
(2.6)\end{array}$ & $\begin{array}{c}1 \\
(2.6)\end{array}$ & $\begin{array}{c}24 \\
(61.5)\end{array}$ & $\begin{array}{c}13 \\
(33.3)\end{array}$ & $\begin{array}{c}39 \\
(100)\end{array}$ & 4.3077 & .61361 & .377 \\
\hline
\end{tabular}




\begin{tabular}{|c|c|c|c|c|c|c|c|c|c|c|}
\hline $\mathbf{S} / \mathbf{N}$ & Statement & $\begin{array}{l}\text { SA } \\
(\%)\end{array}$ & $\begin{array}{c}A \\
(\%)\end{array}$ & $\begin{array}{c}\mathrm{U} \\
(\%)\end{array}$ & $\begin{array}{c}D \\
(\%)\end{array}$ & $\begin{array}{l}\text { SD } \\
(\%)\end{array}$ & Total & Mean & St.D & CV\% \\
\hline 12. & $\begin{array}{l}\text { Due to the recent } \\
\text { violent crisis, there } \\
\text { was significant } \\
\text { decrease in } \\
\text { economic } \\
\text { development in the } \\
\text { study area. }\end{array}$ & $\begin{array}{c}24 \\
(61.5)\end{array}$ & $\begin{array}{c}14 \\
(35.9)\end{array}$ & $\begin{array}{c}1 \\
(2.6)\end{array}$ & $\begin{array}{c}0 \\
(0.0)\end{array}$ & $\begin{array}{c}0 \\
(0.0)\end{array}$ & $\begin{array}{c}39 \\
(100)\end{array}$ & 1.4103 & .54858 & .301 \\
\hline 13. & $\begin{array}{l}\text { And because the } \\
\text { substructure } \\
\text { (economic) was } \\
\text { affected by the } \\
\text { crises, other social } \\
\text { aspects of the } \\
\text { people were also } \\
\text { affected. }\end{array}$ & $\begin{array}{c}26 \\
(66.7)\end{array}$ & $\begin{array}{c}13 \\
(33.3)\end{array}$ & $\begin{array}{c}0 \\
(0.0)\end{array}$ & $\begin{array}{c}0 \\
(0.0)\end{array}$ & $\begin{array}{c}0 \\
(0.0)\end{array}$ & $\begin{array}{c}39 \\
(100)\end{array}$ & 1.3333 & .47757 & .228 \\
\hline
\end{tabular}

Table 4: Responses of Respondents on the Causes and Impacts of Violent Crisis in Gindin-Dorowa between 2012 and 2017

Source: Field Survey (2018)

$S A=$ Strongly Agree, $A=$ Agree,$U=$ Undecided $D=$ Disagree, $S D=$ Strongly Disagree, $S T . D=$ Standard Deviation, $C V=$ Coefficient of Variation

\begin{tabular}{|c|c|c|c|c|c|c|c|c|c|c|}
\hline $\mathrm{S} / \mathrm{N}$ & Statement & $\begin{array}{c}\text { SA } \\
(\%)\end{array}$ & $\begin{array}{c}A \\
(\%)\end{array}$ & $\begin{array}{c}\mathrm{U} \\
(\%)\end{array}$ & $\begin{array}{c}\mathrm{D} \\
(\%)\end{array}$ & $\begin{array}{c}\text { SD } \\
(\%)\end{array}$ & Total & Mean & St.D & $\mathrm{CV}$ \\
\hline 1. & $\begin{array}{c}\text { The recent violent } \\
\text { crisis (2012-2017) } \\
\text { in your locality was } \\
\text { influenced by } \\
\text { ethnicity } \\
\text { (intra/inter). }\end{array}$ & $\begin{array}{c}9 \\
(19.6)\end{array}$ & $\begin{array}{c}9 \\
(19.6)\end{array}$ & $\begin{array}{c}3 \\
(6.5)\end{array}$ & $\begin{array}{c}17 \\
(37.0)\end{array}$ & $\begin{array}{c}8 \\
(17.4)\end{array}$ & $\begin{array}{c}46 \\
(100)\end{array}$ & 3.1304 & 1.43927 & 2.071 \\
\hline 2. & $\begin{array}{l}\text { The violent crisis in } \\
\text { your locality was } \\
\text { caused by religious } \\
\text { extremism. }\end{array}$ & $\begin{array}{c}27 \\
(58.7)\end{array}$ & $\begin{array}{c}14 \\
(30.4)\end{array}$ & $\begin{array}{c}2 \\
(4.3)\end{array}$ & $\begin{array}{c}3 \\
(6.5)\end{array}$ & $\begin{array}{c}0 \\
(0.0)\end{array}$ & $\begin{array}{c}46 \\
(100)\end{array}$ & 1.5870 & .85832 & .737 \\
\hline 3. & $\begin{array}{l}\text { The violent crisis in } \\
\text { your locality was } \\
\text { caused by the } \\
\text { struggle between } \\
\text { nomadic herdsmen } \\
\text { and farmers. }\end{array}$ & $\begin{array}{c}15 \\
(32.6)\end{array}$ & $\begin{array}{c}26 \\
(56.5)\end{array}$ & $\begin{array}{c}3 \\
(6.5)\end{array}$ & $\begin{array}{c}0 \\
(0.0)\end{array}$ & $\begin{array}{c}2 \\
(4.3)\end{array}$ & $\begin{array}{c}46 \\
(100)\end{array}$ & 1.8696 & .88465 & .783 \\
\hline 4. & $\begin{array}{l}\text { The violent crisis in } \\
\text { your locality was } \\
\text { politically } \\
\text { influenced. }\end{array}$ & $\begin{array}{c}12 \\
(26.1)\end{array}$ & $\begin{array}{c}18 \\
(39.1)\end{array}$ & $\begin{array}{c}9 \\
(19.6)\end{array}$ & $\begin{array}{c}6 \\
(13.0)\end{array}$ & $\begin{array}{c}1 \\
(2.2)\end{array}$ & $\begin{array}{c}46 \\
(100)\end{array}$ & 2.2609 & 1.06322 & 1.130 \\
\hline 5. & $\begin{array}{l}\text { The crisis in your } \\
\text { locality was } \\
\text { influenced by } \\
\text { economic trading } \\
\text { (struggle for scarce } \\
\text { resource or market } \\
\text { dominance). }\end{array}$ & $\begin{array}{c}3 \\
(6.5)\end{array}$ & $\begin{array}{c}7 \\
(15.2)\end{array}$ & $\begin{array}{c}7 \\
(15.2)\end{array}$ & $\begin{array}{c}20 \\
(43.5)\end{array}$ & $\begin{array}{c}9 \\
(19.6)\end{array}$ & $\begin{array}{c}46 \\
(100)\end{array}$ & 3.5435 & 1.16822 & 1.365 \\
\hline 6. & $\begin{array}{l}\text { The crisis in your } \\
\text { locality was as a } \\
\text { result of struggle } \\
\text { between indigenes } \\
\text { \& settlers }\end{array}$ & $\begin{array}{c}5 \\
(10.9)\end{array}$ & $\begin{array}{c}5 \\
(10.9)\end{array}$ & $\begin{array}{c}3 \\
(6.5)\end{array}$ & $\begin{array}{c}24 \\
(52.2)\end{array}$ & $\begin{array}{c}9 \\
(19.6)\end{array}$ & $\begin{array}{c}46 \\
(100)\end{array}$ & 3.5870 & 1.23964 & 1.537 \\
\hline 7. & $\begin{array}{c}\text { The recent violent } \\
\text { crisis of 2012-2017 } \\
\text { impacted, positively } \\
\text { on the economic } \\
\text { activities/productio } \\
\mathrm{n} \text { in the study area. }\end{array}$ & $\begin{array}{c}1 \\
(2.2)\end{array}$ & $\begin{array}{c}1 \\
(2.2)\end{array}$ & $\begin{array}{c}4 \\
(8.7)\end{array}$ & $\begin{array}{c}15 \\
(32.6)\end{array}$ & $\begin{array}{c}25 \\
(54.3)\end{array}$ & $\begin{array}{c}46 \\
(100)\end{array}$ & 4.3478 & .89981 & .810 \\
\hline 8. & $\begin{array}{l}\text { The recent violent } \\
\text { crisis of 2012-2017 } \\
\text { impacted, negatively } \\
\text { on the economic } \\
\text { activities/productio } \\
\mathrm{n} \text { in the study area. }\end{array}$ & $\begin{array}{c}25 \\
(54.3)\end{array}$ & $\begin{array}{c}17 \\
(37.0)\end{array}$ & $\begin{array}{c}3 \\
(6.5)\end{array}$ & $\begin{array}{c}1 \\
(2.2)\end{array}$ & $\begin{array}{c}0 \\
(0.0)\end{array}$ & $\begin{array}{c}46 \\
(100)\end{array}$ & 1.5652 & .71963 & .518 \\
\hline
\end{tabular}




\begin{tabular}{|c|c|c|c|c|c|c|c|c|c|c|}
\hline $\mathrm{S} / \mathrm{N}$ & Statement & $\begin{array}{c}\text { SA } \\
(\%)\end{array}$ & $\begin{array}{c}\text { A } \\
(\%)\end{array}$ & $\begin{array}{c}U \\
(\%)\end{array}$ & $\begin{array}{c}\text { D } \\
(\%)\end{array}$ & $\begin{array}{l}\text { SD } \\
(\%)\end{array}$ & Total & Mean & St.D & $\mathrm{CV}$ \\
\hline 9. & $\begin{array}{l}\text { As a result of the } \\
\text { recent violent crisis } \\
\text { in your locality, } \\
\text { there was great } \\
\text { increase in income } \\
\text { level and spending } \\
\text { power of the locales. }\end{array}$ & $\begin{array}{c}8 \\
(17.4)\end{array}$ & $\begin{array}{c}4 \\
(8.7)\end{array}$ & $\begin{array}{c}9 \\
(19.6)\end{array}$ & $\begin{array}{c}13 \\
(28.3)\end{array}$ & $\begin{array}{c}12 \\
(26.1)\end{array}$ & $\begin{array}{c}46 \\
(100)\end{array}$ & 3.3696 & 1.41984 & 2.016 \\
\hline 10. & $\begin{array}{l}\text { As a result of the } \\
\text { recent violent crisis } \\
\text { in your locality, } \\
\text { there was great } \\
\text { decrease in income } \\
\text { level and spending } \\
\text { power of the locales. }\end{array}$ & $\begin{array}{c}14 \\
(30.4)\end{array}$ & $\begin{array}{c}22 \\
(47.8)\end{array}$ & $\begin{array}{c}1 \\
(2.2)\end{array}$ & $\begin{array}{c}6 \\
(13.0)\end{array}$ & $\begin{array}{c}3 \\
(6.5)\end{array}$ & $\begin{array}{c}46 \\
(100)\end{array}$ & 2.1739 & 1.19823 & 1.436 \\
\hline 11. & $\begin{array}{l}\text { Due to the recent } \\
\text { violent crisis, there } \\
\text { was significant } \\
\text { increase in } \\
\text { economic } \\
\text { development in the } \\
\text { study area. }\end{array}$ & $\begin{array}{c}1 \\
(2.2)\end{array}$ & $\begin{array}{c}0 \\
(0.0)\end{array}$ & $\begin{array}{c}2 \\
(4.3)\end{array}$ & $\begin{array}{c}15 \\
(32.6)\end{array}$ & $\begin{array}{c}28 \\
(60.9)\end{array}$ & $\begin{array}{c}46 \\
(100)\end{array}$ & 4.5000 & .78174 & .611 \\
\hline 12. & $\begin{array}{l}\text { Due to the recent } \\
\text { violent crisis, there } \\
\text { was significant } \\
\text { decrease in } \\
\text { economic } \\
\text { development in the } \\
\text { study area. } \\
\end{array}$ & $\begin{array}{c}32 \\
(69.6)\end{array}$ & $\begin{array}{c}13 \\
(28.3)\end{array}$ & $\begin{array}{c}0 \\
(0.0)\end{array}$ & $\begin{array}{c}0 \\
(0.0)\end{array}$ & $\begin{array}{c}1 \\
(2.2)\end{array}$ & $\begin{array}{c}46 \\
(100)\end{array}$ & 1.3696 & .71051 & .505 \\
\hline 13. & $\begin{array}{l}\text { And because the } \\
\text { substructure } \\
\text { (economic) was } \\
\text { affected by the } \\
\text { crises, other social } \\
\text { aspects of the } \\
\text { people were also } \\
\text { affected. }\end{array}$ & $\begin{array}{c}10 \\
(21.7)\end{array}$ & $\begin{array}{c}36 \\
(78.3)\end{array}$ & $\begin{array}{c}0 \\
(0.0)\end{array}$ & $\begin{array}{c}0 \\
(0.0)\end{array}$ & $\begin{array}{c}0 \\
(0.0)\end{array}$ & $\begin{array}{c}46 \\
(100)\end{array}$ & 1.7826 & .41703 & .174 \\
\hline
\end{tabular}

Table 5: Responses of Respondents on the Causes and Impacts of Violent Crisis in

Kente between 2012 and 2017

Source: Field Survey (2018)

$S A=$ Strongly Agree, $A=$ Agree, $U=$ Undecided, $D=$ Disagree, $S D=$ Strongly Disagree, ST.D = Standard Deviation, $C V=$ Coefficient of Variation

Table 5 displayed information on the responses of respondents about the causes and impacts of violent crises in Kente from 2012 - 2017. The result revealed that $54.4 \%$ (i.e. $37.0 \%$ D and $17.4 \%$ SD) disagreed with the postulation which states that the crisis was influenced by intra/inter-ethnic antagonism. In the same vein, most of the respondents said that the crisis was not an indigene-settlers struggle nor influenced by economic trading or struggle for scarce resource/market dominance among the locales (Table 5). On the contrary, 89.1\% (i.e. 58.7\% Strongly Agreed and 30.1\% Agreed) indicated that the crisis was significantly influence by religious extremism, which was linked to herders-farmers struggle (89.1\%)in the area while $65.2 \%$ said the crisis was also politically influenced. This result agrees with what other scholars have written about the causes of violent crises in the society. For example, many researchers identified the causes of violent crisis in almost all human societies to include: crisis over resources, crisis involving values, crisis over psychological needs, crisis arising from ethno-religious intolerance, etc. (Drukkman, 1993; Folger, 1997; Oyedolapo, 2013; Charles, 2016).

Also, from Table 5, 87\% of the respondents disagreed with the assertion which states that the crises (20122017) impacted positively on the economic activities/production in the area. Moreover, $54.3 \%$ (with a mean value of 3.37 ) disagreed with the question whether the crises greatly increase income level and purchasing/spending power of the people, and a total of $94.5 \%$ with a mean value of 4.50 also strongly disagreed with the statement which says that there was significantly increase in economic development in the area. Still on the Table, responses on the impacts of the crisis in Kente revealed that $42(91.3 \%)$ of the respondents agreed that the crises impacted negatively on the economic production of the people while $36(78.3 \%)$ of them said there was decrease in income level of the locales because the people were living under the fear of attack as their major source of income is farming which has been dislocated following nomadic herdsmen-farmers clashes around the area. In addition to this, only 1 respondent refuted the statement that "there was significant decrease in economic development in the area" which means that $97.8 \%$ agreed that these inhumane activities affected the social wellbeing of the people as well as paralyzed development strides of the area. Conversely, all the 46 respondents agreed with the postulation that since the economic based was affected, other social aspects of the people were also affected (Table 5). This problem as noted by the respondents is in line with what had been observed so far in 
this work and other reports by researchers like Saheed and Egwaikhide (2012), Ali et al. (2014) and Onwe et al. (2015) on their studies of the effects of conflicts in various parts of the country.

In Table 6, religious extremism and nomadic herdsmen-farmers struggle were said to be major causes of crises in Sondi because both had 41 (93.2\%) responses out of 44 respondents. Next was 25 (56.8\%) respondents who supported that the crises in the area were politically influenced. It was noted that $21(47.7 \%), 25(56.8 \%)$ and $27(61.4 \%)$ respondents disagreed with the statements on serial numbers 1, 5 and 6 of the Table which implies that the crises in Sondi were neither influenced by ethnicity, nor struggle for economic trading/market dominance or indigenes-settlers' quest, respectively.The result on the impacts of the crises in Sondi also revealed that all the 44 (i.e. 12 SA and 32 A) respondents supported the proposition that the crises impacted negatively on economic production while 42 (95.5\%) out of the 44 respondents agreed with the statements that the crises greatly decreased income level/spending power of the locales and also significantly decreased economic development in the area (Table 6). Moreover, responses indicated that due to the devastated impact of the crises on the based-structure, various social aspects of the people in the community were also affected negatively.

\begin{tabular}{|c|c|c|c|c|c|c|c|c|c|c|}
\hline S/N & Statement & $\begin{array}{c}\text { SA } \\
(\%)\end{array}$ & $\begin{array}{c}\text { A } \\
(\%)\end{array}$ & $\begin{array}{c}U \\
(\%)\end{array}$ & $\begin{array}{c}\text { D } \\
(\%)\end{array}$ & $\begin{array}{l}\text { SD } \\
(\%)\end{array}$ & Total & Mean & St.D & $\mathrm{CV}$ \\
\hline 1. & $\begin{array}{l}\text { The recent violent crisis } \\
\text { (2012-2017) in your } \\
\text { locality was influenced by } \\
\text { ethnicity (intra/inter). }\end{array}$ & $\begin{array}{c}8 \\
(18.2)\end{array}$ & $\begin{array}{c}6 \\
(13.6)\end{array}$ & $\begin{array}{c}9 \\
(20.5)\end{array}$ & $\begin{array}{c}15 \\
(34.1)\end{array}$ & $\begin{array}{c}6 \\
(13.6)\end{array}$ & $\begin{array}{c}44 \\
(100)\end{array}$ & 3.2500 & 1.31406 & 1.727 \\
\hline 2. & $\begin{array}{l}\text { The violent crisis in your } \\
\text { locality was caused by } \\
\text { religious extremism. }\end{array}$ & $\begin{array}{c}19 \\
(43.2)\end{array}$ & $\begin{array}{c}22 \\
(50.0)\end{array}$ & $\begin{array}{c}1 \\
(2.3)\end{array}$ & $\begin{array}{c}1 \\
(2.3)\end{array}$ & $\begin{array}{c}1 \\
(2.3)\end{array}$ & $\begin{array}{c}44 \\
(100)\end{array}$ & 1.7045 & .82348 & .678 \\
\hline 3. & $\begin{array}{l}\text { The violent crisis in your } \\
\text { locality was caused by the } \\
\text { struggle between nomadic } \\
\text { herdsmen and farmers. }\end{array}$ & $\begin{array}{c}18 \\
(40.9)\end{array}$ & $\begin{array}{c}23 \\
(52.3)\end{array}$ & $\begin{array}{c}2 \\
(4.5)\end{array}$ & $\begin{array}{c}1 \\
(2.3)\end{array}$ & $\begin{array}{c}0 \\
(0.0)\end{array}$ & $\begin{array}{c}44 \\
(100)\end{array}$ & 1.6818 & .67420 & .455 \\
\hline 4. & $\begin{array}{c}\text { The violent crisis in your } \\
\text { locality was politically } \\
\text { influenced. }\end{array}$ & $\begin{array}{c}12 \\
(27.3)\end{array}$ & $\begin{array}{c}13 \\
(29.5)\end{array}$ & $\begin{array}{c}9 \\
(20.5)\end{array}$ & $\begin{array}{c}10 \\
(22.7)\end{array}$ & $\begin{array}{c}0 \\
(0.0)\end{array}$ & $\begin{array}{c}44 \\
(100)\end{array}$ & 2.3864 & 1.12510 & 1.266 \\
\hline 5. & $\begin{array}{l}\text { The crisis in your locality } \\
\text { was influenced by } \\
\text { economic trading } \\
\text { (struggle for scarce } \\
\text { resource or market } \\
\text { dominance). }\end{array}$ & $\begin{array}{c}1 \\
(2.3)\end{array}$ & $\begin{array}{c}2 \\
(4.5)\end{array}$ & $\begin{array}{c}16 \\
(36.4)\end{array}$ & $\begin{array}{c}23 \\
(52.3)\end{array}$ & $\begin{array}{c}2 \\
(4.5)\end{array}$ & $\begin{array}{c}44 \\
(100)\end{array}$ & 3.5227 & .76215 & .581 \\
\hline 6. & $\begin{array}{c}\text { The crisis in your locality } \\
\text { was as a result of struggle } \\
\text { between indigenes \& } \\
\text { settlers }\end{array}$ & $\begin{array}{c}6 \\
(13.6)\end{array}$ & $\begin{array}{c}5 \\
(11.4)\end{array}$ & $\begin{array}{c}6 \\
(13.6)\end{array}$ & $\begin{array}{c}21 \\
(47.7)\end{array}$ & $\begin{array}{c}6 \\
(13.6)\end{array}$ & $\begin{array}{c}44 \\
(100)\end{array}$ & 3.3636 & 1.25922 & 1.586 \\
\hline 7. & $\begin{array}{l}\text { The recent violent crisis of } \\
2012-2017 \text { impacted, } \\
\text { positively on the economic } \\
\text { activities/production in } \\
\text { the study area. }\end{array}$ & $\begin{array}{c}0 \\
(0.0)\end{array}$ & $\begin{array}{c}0 \\
(0.0)\end{array}$ & $\begin{array}{c}3 \\
(6.8)\end{array}$ & $\begin{array}{c}22 \\
(50.0)\end{array}$ & $\begin{array}{c}19 \\
(43.2)\end{array}$ & $\begin{array}{c}44 \\
(100)\end{array}$ & 4.3636 & .61345 & .376 \\
\hline 8. & $\begin{array}{l}\text { The recent violent crisis of } \\
2012-2017 \text { impacted, } \\
\text { negatively on the } \\
\text { economic } \\
\text { activities/production in } \\
\text { the study area. }\end{array}$ & $\begin{array}{c}12 \\
(27.3)\end{array}$ & $\begin{array}{c}32 \\
(72.7)\end{array}$ & $\begin{array}{c}0 \\
(0.0)\end{array}$ & $\begin{array}{c}0 \\
(0.0)\end{array}$ & $\begin{array}{c}0 \\
(0.0)\end{array}$ & $\begin{array}{c}44 \\
(100)\end{array}$ & 1.7273 & .45051 & .203 \\
\hline 9. & $\begin{array}{l}\text { As a result of the recent } \\
\text { violent crisis in your } \\
\text { locality, there was great } \\
\text { increase in income level } \\
\text { and spending power of } \\
\text { the locales. }\end{array}$ & $\begin{array}{c}2 \\
(4.5)\end{array}$ & $\begin{array}{c}1 \\
(2.3)\end{array}$ & $\begin{array}{c}4 \\
(9.1)\end{array}$ & $\begin{array}{c}27 \\
(61.4)\end{array}$ & $\begin{array}{c}10 \\
(22.7)\end{array}$ & $\begin{array}{c}44 \\
(100)\end{array}$ & 3.9545 & .91384 & .835 \\
\hline 10. & $\begin{array}{l}\text { As a result of the recent } \\
\text { violent crisis in your } \\
\text { locality, there was great } \\
\text { decrease in income level } \\
\text { and spending power of } \\
\text { the locales. }\end{array}$ & $\begin{array}{c}10 \\
(22.7)\end{array}$ & $\begin{array}{c}32 \\
(72.7)\end{array}$ & $\begin{array}{c}2 \\
(4.5)\end{array}$ & $\begin{array}{c}0 \\
(0.0)\end{array}$ & $\begin{array}{c}0 \\
(0.0)\end{array}$ & $\begin{array}{c}44 \\
(100)\end{array}$ & 1.8182 & .49522 & .245 \\
\hline 11. & $\begin{array}{l}\text { Due to the recent violent } \\
\text { crisis, there was } \\
\text { significant increase in } \\
\text { economic development in } \\
\text { the study area. }\end{array}$ & $\begin{array}{c}0 \\
(0.0)\end{array}$ & $\begin{array}{c}0 \\
(0.0)\end{array}$ & $\begin{array}{c}1 \\
(2.3)\end{array}$ & $\begin{array}{c}27 \\
(61.4)\end{array}$ & $\begin{array}{c}16 \\
(36.4)\end{array}$ & $\begin{array}{c}44 \\
(100)\end{array}$ & 4.3409 & .52576 & .276 \\
\hline
\end{tabular}




\begin{tabular}{|c|c|c|c|c|c|c|c|c|c|c|}
\hline S/N & Statement & $\begin{array}{c}\text { SA } \\
(\%)\end{array}$ & $\begin{array}{c}A \\
(\%)\end{array}$ & $\begin{array}{c}\text { U } \\
(\%)\end{array}$ & $\begin{array}{c}D \\
(\%)\end{array}$ & $\begin{array}{c}\text { SD } \\
(\%)\end{array}$ & Total & Mean & St.D & $\mathbf{C V}$ \\
\hline 12. & $\begin{array}{l}\text { Due to the recent violent } \\
\text { crisis, there was } \\
\text { significant decrease in } \\
\text { economic development in } \\
\text { the study area. }\end{array}$ & $\begin{array}{c}24 \\
(54.5)\end{array}$ & $\begin{array}{c}18 \\
(40.9)\end{array}$ & $\begin{array}{c}1 \\
(2.3)\end{array}$ & $\begin{array}{c}0 \\
(0.0)\end{array}$ & $\begin{array}{c}1 \\
(2.3)\end{array}$ & $\begin{array}{c}44 \\
(100)\end{array}$ & 1.5455 & .76111 & .579 \\
\hline 13. & $\begin{array}{l}\text { And because the } \\
\text { substructure (economic) } \\
\text { was affected by the crises, } \\
\text { other social aspects of the } \\
\text { people were also affected. }\end{array}$ & $\begin{array}{c}20 \\
(45.5)\end{array}$ & $\begin{array}{c}24 \\
(54.5)\end{array}$ & $\begin{array}{c}0 \\
(0.0)\end{array}$ & $\begin{array}{c}0 \\
(0.0)\end{array}$ & $\begin{array}{c}0 \\
(0.0)\end{array}$ & $\begin{array}{c}44 \\
(100)\end{array}$ & 1.5455 & .50369 & .254 \\
\hline
\end{tabular}

Table 6: Responses of Respondents on the Causes and Impacts of Violent Crisis in Sondi between 2012 and 2017 Source: Field Survey (2018)

$S A=$ Strongly Agree, $A=$ Agree,$U=$ Undecided $D=$ Disagree,$S D=$ Strongly Disagree, $S t . D=$ Standard Deviation, $C V=$ Coefficient of Variation Occurrence

\begin{tabular}{|c|c|c|c|c|c|c|c|c|c|c|}
\hline $\mathrm{S} / \mathrm{N}$ & Statement & $\begin{array}{c}\text { SA } \\
(\%)\end{array}$ & $\begin{array}{c}A \\
(\%)\end{array}$ & $\begin{array}{c}U \\
(\%)\end{array}$ & $\begin{array}{c} \\
(\%)\end{array}$ & $\begin{array}{l}\text { SD } \\
(\%)\end{array}$ & Total & Mean & St.D & $\mathrm{CV}$ \\
\hline 1. & $\begin{array}{c}\text { The recent violent } \\
\text { crisis (2012-2017) } \\
\text { in your locality was } \\
\text { influenced by } \\
\text { ethnicity } \\
\text { (intra/inter). }\end{array}$ & $\begin{array}{c}29 \\
(21.0)\end{array}$ & $\begin{array}{c}24 \\
(17.4)\end{array}$ & $\begin{array}{c}16 \\
(11.6)\end{array}$ & $\begin{array}{c}47 \\
(34.1)\end{array}$ & $\begin{array}{c}22 \\
(15.9)\end{array}$ & $\begin{array}{c}138 \\
(100)\end{array}$ & 3.0652 & 1.41528 & 2.003 \\
\hline 2. & $\begin{array}{l}\text { The violent crisis in } \\
\text { your locality was } \\
\text { caused by religious } \\
\text { extremism. }\end{array}$ & $\begin{array}{c}70 \\
(50.7)\end{array}$ & $\begin{array}{c}53 \\
(38.4)\end{array}$ & $\begin{array}{c}6 \\
(4.3)\end{array}$ & $\begin{array}{c}6 \\
(4.3)\end{array}$ & $\begin{array}{c}3 \\
(2.2)\end{array}$ & $\begin{array}{c}138 \\
(100)\end{array}$ & 1.6884 & .91061 & .829 \\
\hline 3. & $\begin{array}{l}\text { The violent crisis in } \\
\text { your locality was } \\
\text { caused by the } \\
\text { struggle between } \\
\text { nomadic herdsmen } \\
\text { and farmers. }\end{array}$ & $\begin{array}{c}17 \\
(12.3)\end{array}$ & $\begin{array}{c}30 \\
(21.7)\end{array}$ & $\begin{array}{c}12 \\
(8.7)\end{array}$ & $\begin{array}{c}54 \\
(39.1)\end{array}$ & $\begin{array}{c}25 \\
(18.1)\end{array}$ & $\begin{array}{c}138 \\
(100)\end{array}$ & 3.2899 & 1.32468 & 1.755 \\
\hline 4. & $\begin{array}{c}\text { The violent crisis in } \\
\text { your locality was } \\
\text { politically } \\
\text { influenced. }\end{array}$ & $\begin{array}{c}51 \\
(37.0)\end{array}$ & $\begin{array}{c}42 \\
(30.4)\end{array}$ & $\begin{array}{c}17 \\
(12.3)\end{array}$ & $\begin{array}{c}18 \\
(13.0)\end{array}$ & $\begin{array}{c}10 \\
(7.2)\end{array}$ & $\begin{array}{c}138 \\
(100)\end{array}$ & 2.2319 & 1.30034 & 1.691 \\
\hline 5. & $\begin{array}{l}\text { The crisis in your } \\
\text { locality was } \\
\text { influenced by } \\
\text { economic trading } \\
\text { (struggle for scarce } \\
\text { resource or market } \\
\text { dominance). }\end{array}$ & $\begin{array}{c}16 \\
(11.6)\end{array}$ & $\begin{array}{c}57 \\
(41.3)\end{array}$ & $\begin{array}{c}15 \\
(10.9)\end{array}$ & $\begin{array}{c}29 \\
(21.00\end{array}$ & $\begin{array}{c}21 \\
(15.2)\end{array}$ & $\begin{array}{c}138 \\
(100)\end{array}$ & 2.8696 & 1.22764 & 1.507 \\
\hline 6. & $\begin{array}{l}\text { The crisis in your } \\
\text { locality was as a } \\
\text { result of struggle } \\
\text { between indigenes } \\
\text { \& settlers }\end{array}$ & $\begin{array}{c}29 \\
(21.0 \\
0\end{array}$ & $\begin{array}{c}48 \\
(34.8)\end{array}$ & $\begin{array}{c}10 \\
(7.2)\end{array}$ & $\begin{array}{c}31 \\
(22.5)\end{array}$ & $\begin{array}{c}20 \\
(14.5)\end{array}$ & $\begin{array}{c}138 \\
(100)\end{array}$ & 2.7464 & 1.39374 & 1.943 \\
\hline 7. & $\begin{array}{l}\text { The recent violent } \\
\text { crisis of 2012- } \\
2017 \text { impacted, } \\
\text { positively on the } \\
\text { economic } \\
\text { activities/producti } \\
\text { on in the study } \\
\text { area. }\end{array}$ & $\begin{array}{c}7 \\
(5.1)\end{array}$ & $\begin{array}{c}9 \\
(6.5)\end{array}$ & $\begin{array}{c}6 \\
(4.3)\end{array}$ & $\begin{array}{c}46 \\
(33.3)\end{array}$ & $\begin{array}{c}70 \\
(50.7)\end{array}$ & $\begin{array}{c}138 \\
(100)\end{array}$ & 4.1812 & 1.11549 & 1.244 \\
\hline 8. & $\begin{array}{l}\text { The recent violent } \\
\text { crisis of 2012- } \\
2017 \text { impacted, } \\
\text { negatively on the } \\
\text { economic } \\
\text { activities/producti } \\
\text { on in the study } \\
\text { area. }\end{array}$ & $\begin{array}{c}81 \\
(58.7)\end{array}$ & $\begin{array}{c}45 \\
(32.6)\end{array}$ & $\begin{array}{c}5 \\
(3.6)\end{array}$ & $\begin{array}{c}6 \\
(4.3)\end{array}$ & $\begin{array}{c}1 \\
(0.7)\end{array}$ & $\begin{array}{c}138 \\
(100)\end{array}$ & 1.5580 & .81963 & .672 \\
\hline
\end{tabular}




\begin{tabular}{|c|c|c|c|c|c|c|c|c|c|c|}
\hline S/N & Statement & $\begin{array}{l}\text { SA } \\
(\%)\end{array}$ & $\begin{array}{c}A \\
(\%)\end{array}$ & $\begin{array}{c}U \\
(\%)\end{array}$ & $\begin{array}{c}\text { D } \\
(\%)\end{array}$ & $\begin{array}{l}\text { SD } \\
(\%)\end{array}$ & Total & Mean & St.D & $\mathrm{CV}$ \\
\hline 9. & $\begin{array}{l}\text { As a result of the } \\
\text { recent violent crisis } \\
\text { in your locality, } \\
\text { there was great } \\
\text { increase in income } \\
\text { level and spending } \\
\text { power of the } \\
\text { locales. }\end{array}$ & $\begin{array}{c}4 \\
(2.9)\end{array}$ & $\begin{array}{c}6 \\
(4.3)\end{array}$ & $\begin{array}{c}7 \\
(5.1)\end{array}$ & $\begin{array}{c}66 \\
(47.8)\end{array}$ & $\begin{array}{c}55 \\
(39.9)\end{array}$ & $\begin{array}{c}138 \\
(100)\end{array}$ & 4.1739 & .92739 & .860 \\
\hline 10. & $\begin{array}{l}\text { As a result of the } \\
\text { recent violent crisis } \\
\text { in your locality, } \\
\text { there was great } \\
\text { decrease in income } \\
\text { level and spending } \\
\text { power of the } \\
\text { locales. }\end{array}$ & $\begin{array}{c}67 \\
(48.6)\end{array}$ & $\begin{array}{c}57 \\
(41.3)\end{array}$ & $\begin{array}{c}6 \\
(4.3)\end{array}$ & $\begin{array}{c}3 \\
(2.2)\end{array}$ & $\begin{array}{c}5 \\
(3.6)\end{array}$ & $\begin{array}{c}138 \\
(100)\end{array}$ & 1.7101 & .92966 & .864 \\
\hline 11. & $\begin{array}{l}\text { Due to the recent } \\
\text { violent crisis, there } \\
\text { was significant } \\
\text { increase in } \\
\text { economic } \\
\text { development in the } \\
\text { study area. }\end{array}$ & $\begin{array}{c}3 \\
(2.2)\end{array}$ & $\begin{array}{c}7 \\
(5.1)\end{array}$ & $\begin{array}{c}10 \\
(7.2)\end{array}$ & $\begin{array}{c}58 \\
(42.0)\end{array}$ & $\begin{array}{c}60 \\
(43.5)\end{array}$ & $\begin{array}{c}138 \\
(100)\end{array}$ & 4.1957 & .93480 & .874 \\
\hline 12. & $\begin{array}{l}\text { Due to the recent } \\
\text { violent crisis, there } \\
\text { was significant } \\
\text { decrease in } \\
\text { economic } \\
\text { development in the } \\
\text { study area. }\end{array}$ & $\begin{array}{c}73 \\
(52.9)\end{array}$ & $\begin{array}{c}52 \\
(37.7)\end{array}$ & $\begin{array}{c}3 \\
(2.2)\end{array}$ & $\begin{array}{c}4 \\
(2.9)\end{array}$ & $\begin{array}{c}6 \\
(4.3)\end{array}$ & $\begin{array}{c}138 \\
(100)\end{array}$ & 1.6812 & .98147 & .963 \\
\hline 13. & $\begin{array}{l}\text { And because the } \\
\text { substructure } \\
\text { (economic) was } \\
\text { affected by the } \\
\text { crises, other social } \\
\text { aspects of the } \\
\text { people were also } \\
\text { affected. }\end{array}$ & $\begin{array}{c}91 \\
(65.9)\end{array}$ & $\begin{array}{c}42 \\
(30.4)\end{array}$ & $\begin{array}{c}0 \\
(0.0)\end{array}$ & $\begin{array}{c}1 \\
(0.7)\end{array}$ & $\begin{array}{c}4 \\
(2.9)\end{array}$ & $\begin{array}{c}138 \\
(100)\end{array}$ & 1.4420 & .80162 & .643 \\
\hline
\end{tabular}

Table 7: Responses of Respondents on the Causes and Impacts of Violent Crisis in Wukari-Town between 2012 and 2017

Source: Field Survey (2018)

$S A=$ Strongly Agree, $A=$ Agree,$U=$ Undecided, $D=$ Disagree, $S D=$ Strongly Disagree, St. $D=$ Standard Deviation, $C V=$ Coefficient of Variation

For inputs of respondents on the causes and impacts of crises in Wukari-town, Table 7 provided statistical information on topical statements concerning the research topic. In the Table, responses on whether the violent crisis was as a result of intra/inter ethnicity or not; the study shows that $50 \%$ of the respondents disagreed while $38.4 \%$ agreed and undecided scored $11.6 \%$. On the other hand, a whopping percentage of 89.1 with a mean value of 1.69 strongly agreed that the incessant crisis was greatly influenced by religious bigotry. The result also indicated that violent crises within the period under study was not caused by herdsmen-farmers struggle since $57.2 \%$ of the respondents attested to this fact, while $34.1 \%$ said the crises was influenced by threatened activities of nomadic herdsmen within the locality (Table 7). Another issue of concern is the question whether the violent crisis in Wukari-town was politically influenced. On this note, the result obtained for this work shows that $67.4 \%$ of the respondents said both local government and state political trends (especially between 2012 and 2015) also contributed to the outbreak of the crises of Wukari-town in which lives were loss and properties damaged. Following the responses of respondents on serial numbers 5 and 6 of the Table, $52.9 \%$ said the crisis was influenced by struggle for economic trading/market dominance among the people while $36.2 \%$ disagreed with that position. Similarly, 55.8\% of the respondents agreed that the crisis was triggered by hostile struggle between Christian indigenes and Moslem settlers while 37.0\% disagreed and 7.2\% falls under Undecided column.

Responding to the postulations on the socioeconomic impacts of the crises, only $16(11.6 \%)$ agreed that the crises impacted positively on economic activities/production of the area whereas $116(84.1 \%)$ respondents strongly disagreed. On the contrary, 128 (91.3\%) respondents said the crises impacted negatively on economic production in the area with only $5 \%$ of them opposed the above postulation (Table 7). The result also disclosed that only $7.2 \%$ respondents agreed that there was great increase in purchasingpower of the inhabitants with $5.1 \%$ Undecided; whereas $87.7 \%$ disagreed. The Table clearly depicts that $89.9 \%$ (i.e. $48.6 \%$ SA and $41.3 \%$ A) agreed that the crises resulted to great decrease in income level and spending/purchasing power of the locales. Another important thing one must know about the Wukari-town crises is that with the negative impact of the crises on economic activities/production in the area coupled with great 
decrease in income level/spending power, there was great decrease in economic development of the place. This is in line with the responses of the respondents as $90.6 \%$ (52.9 SA and $37.7 \% \mathrm{~A}$ ) attested to it (Table 7). Consequently, the devastated impacts of violent crises on the economic based of the society was said to have severely affected other social aspects of life in almost all ramifications, such as residential segregation along religious divide, increase in crimes rate, including armed robbery as well as persistent suspicious feelings against "the perceived enemy" among the hitherto "closed neighbors and friends or associates" within the community. Furthermore, the result as shown in Table 7,to some extent, corroborates the reports of works of Nwanegbo (2014), Akwara and Charles (2014).

Thus, this kind of relationship is not healthy for, and does not encourage sustainable socioeconomic development. Interestingly, this result corroborates earlier study elsewhere on violent conflict by Ali et al. (2014:308-314) who reported that the aftermath of the crises include: robbery, vandalism, house breaking,mostly perpetrated by the youths and social segregations which resulted from perceived feelings of marginalization, claims of unequal access to economic, social and political opportunities or lack of trust among different groups members in Ussa LGA. The authors also reported that crises in Ussa have led to damages of large number of lives and properties and decrease in people's economic activities, decline in the level of agricultural investment/yield, income levels of the people and increased the level of social and residential segregation. For instance, $133(96.4 \%)$ out of 138 respondents in the current study strongly agreed that because the substructure (economic based) was affected by the crises, other social aspects of the people as noted by Ali et al. (2014) were also affected with only 5(3.6\%) respondents opposing the above supposition.

Comparatively, all the causes of crisis in Wukari LGA as indicated by the respondents were in agreement with what other scholars have identified elsewhere (Drukkman, 1993; Folger, 1997; Oyedolapo, 2013; Charles, 2016); this is also in line with the theoretical explanation of the causes of conflict as adopted in this study.Generally speaking, the Marxist crisis cum Pluralist perspectives as adopted in this study believed that underdevelopment is not only resulting from lack of economic resources and environmental condition, but also largely associated with social relations of the people in a given society. This theoretical compass was able to explain the nature of the society and the topic under discussion.

\subsection{Test of Hypotheses}

- $\mathrm{H}_{0}$ : There was significant increase of economic activities/production, income level, purchasing/spending power of the people and economic development in Wukari LGA as a result of violent crisis between2012 and 2017.

- $\mathrm{H}_{1}$ : There was great decrease in economic activities/production, income level, purchasing/spending power of the people and economic development as a result of violent crises in Wukari LGA between 2012 and 2017.

All responses of respondents regarding the null $\left(\mathrm{H}_{0}\right)$ and alternate $\left(\mathrm{H}_{1}\right)$ hypotheses were summarized as shown in Tables 8 and 9 for the purpose of testing the hypotheses and analysis using mean (and aggregate mean) statistics. The hypothesis with an aggregate mean of any value below 10 is rejected, while the hypothesis with an aggregate mean of any value above 10 is accepted.

\begin{tabular}{|c|c|c|c|c|c|c|c|}
\hline Statement & $\begin{array}{c}\text { Abako } \\
(\mathrm{SA}+\mathrm{A}) \\
(\%)\end{array}$ & $\begin{array}{c}\text { Chinkai } \\
\text { (SA+A) } \\
\text { (\%) }\end{array}$ & $\begin{array}{c}\text { G.D } \\
(S A+A) \\
(\%)\end{array}$ & $\begin{array}{c}\text { Kente } \\
(\mathrm{SA}+\mathrm{A}) \\
(\%)\end{array}$ & $\begin{array}{c}\text { Sondi } \\
(\mathrm{SA}+\mathrm{A}) \\
(\%)\end{array}$ & $\begin{array}{c}\text { W.town } \\
(\mathrm{SA}+\mathrm{A}) \\
(\%)\end{array}$ & Mean \\
\hline $\begin{array}{l}\text { The recent violent crisis of } 2012- \\
2017 \text { impacted, positively on the } \\
\text { economic activities/production } \\
\text { in the study area. }\end{array}$ & 2.1 & 4.9 & 2.6 & 4.4 & 0.0 & 11.6 & 4.27 \\
\hline $\begin{array}{l}\text { As a result of the recent violent } \\
\text { crisis in your locality, there was } \\
\text { great increase in income level } \\
\text { and spending power of the } \\
\text { locales. }\end{array}$ & 2.1 & 0.0 & 5.1 & 26.1 & 6.8 & 7.2 & 7.88 \\
\hline $\begin{array}{l}\text { Due to the recent violent crisis, } \\
\text { there was significant increase in } \\
\text { economic development in the } \\
\text { study area. }\end{array}$ & 2.1 & 0.0 & 2.6 & 2.2 & 0.0 & 7.3 & 2.37 \\
\hline \multicolumn{7}{|c|}{ Aggregate Mean } & 4.84 \\
\hline
\end{tabular}

Table 8: Summary of Correlation of Respondents' Responses on Null $\left(\mathrm{H}_{0}\right)$ Hypothesis

$S A+A=\%$ Score of Strongly Agreed $+\%$ Score of Agreed; G.D = Gindin-Dorowa; W.Town = Wukari-Town 


\begin{tabular}{|c|c|c|c|c|c|c|c|}
\hline Statement & $\begin{array}{c}\text { Abako } \\
(\mathrm{SA}+\mathrm{A}) \\
(\%)\end{array}$ & $\begin{array}{l}\text { Chinkai } \\
(\mathrm{SA}+\mathrm{A}) \\
(\%)\end{array}$ & $\begin{array}{c}\text { G.D } \\
(\mathrm{SA}+\mathrm{A}) \\
(\%)\end{array}$ & $\begin{array}{c}\text { Kente } \\
(\mathrm{SA}+\mathrm{A}) \\
(\%)\end{array}$ & $\begin{array}{c}\text { Sondi } \\
(\mathrm{SA}+\mathrm{A}) \\
(\%)\end{array}$ & $\begin{array}{l}\text { W.town } \\
(\mathrm{SA}+\mathrm{A}) \\
(\%)\end{array}$ & Mean \\
\hline $\begin{array}{l}\text { The recent violent crisis of } \\
\text { 2012-2017 impacted, } \\
\text { negatively on the economic } \\
\text { activities/production in the } \\
\text { study area. }\end{array}$ & 97.9 & 97.6 & 100 & 91.3 & 100 & 91.3 & 96.35 \\
\hline $\begin{array}{c}\text { As a result of the recent } \\
\text { violent crisis in your locality, } \\
\text { there was great decrease in } \\
\text { income level and spending } \\
\text { power of the locales. }\end{array}$ & 100 & 97.6 & 97.4 & 98.2 & 95.5 & 89.9 & 93.10 \\
\hline $\begin{array}{c}\text { Due to the recent violent crisis, } \\
\text { there was significant decrease } \\
\text { in economic development in } \\
\text { the study area. }\end{array}$ & 100 & 100 & 97.4 & 98.8 & 95.4 & 90.6 & 99.03 \\
\hline $\begin{array}{l}\text { And because the substructure } \\
\text { (economic based) was affected } \\
\text { by the crises, other social } \\
\text { aspects of the people were } \\
\text { also affected. }\end{array}$ & 100 & 96.2 & 100 & 100 & 100 & 96.3 & 98.75 \\
\hline \multicolumn{7}{|c|}{ Aggregate Mean } & 64.21 \\
\hline
\end{tabular}

Table 9: Summary of Correlation of Respondents' Responses on the Alternate $\left(\mathrm{H}_{1}\right)$ Hypothesis

$S A+A=\%$ Score of Strongly Agreed $+\%$ Score of Agreed; G.D = Gindin-Dorowa; W.Town = Wukari-Town

The information in Table 8 is a summary of correlation of responses on the null hypothesis which states that there was significant increase of economic activities/production, income level, purchasing/spending power of the people and economic development inWukari LGA as a result of violent crisis between2012 and 2017. While Table 9 presents the alternate hypothesis, which states that there was great decrease in economic activities/production, income level, purchasing/spending power of the people and economic development as a result of violent crises in Wukari LGA between 2012 and 2017 which also affected other social aspect of life. In Table 8 (i.e. $\mathrm{H}_{0}$ hypothesis), mean values of $4.27,7.88$ and 2.37 ,with a calculated aggregate mean value of 4.84 which is far below that of $\mathrm{H}_{1}$ hypothesis as shown in Table 9 with mean values of 96.35, 93.10, 97.03 and 98.75respectively; producing a calculated aggregate mean value of 64.21.

Therefore, the null $\left(\mathrm{H}_{0}\right)$ hypothesis with aggregate mean value of 4.84 is rejected; while the alternate $\mathrm{H}_{1}$ hypothesis with as high as aggregate mean value of 64.21 is accepted. This implies that there was great decrease in economic activities/production, income level, purchasing/spending power of the people and economic development as a result of violent crises in Wukari LGA between 2012 and 2017.

More importantly, the results revealed that other social aspects of life in the area were drastically affected. This assertion is as observed in Table 9 where a calculated mean value of 98.75 was recorded in agreement to the assertion. In other words, approximately $99 \%$ of the sample drespondents of the study said that because the substructure in the area was affected by the crises, the superstructure - other social aspects of the people were also affected negatively. This suggests that the relationship between the crises and economic development in the area was negatively correlated - i.e. the crises translated negatively on socioeconomic wellbeing of the people.

It is worth noting that the impact of the crises in Wukari LGA was not limited to the area alone, but also spilled to neighboring villages and towns of other local governments such as Ibi, Takum, Donga, etc. in Taraba state as well as other neighboring states of the federation, especially Benue, Nasarawa, Plateau and Adamawa, which by implication, it impacted negatively on the overall socioeconomic development of Nigeria as a country. This is in congruence with what Collier and Hoeffler (1998) observed in their study.

Regrettably, most victims of violent crises in Wukari LGA (especially in the villages) had been forced to abandon their place of origin and economic activities only to take refuge in refugee camps for a very long period before they could find new safer or conducive places/towns to settle. In other words, most of them were denied the opportunity to engage in creative activities or to be optimally engaged in their normal economic activities during the crises. Moreover, the study gathered that in most of the crisis areas, both private and public facilities/structures were burnt down or vandalized and survivors or government usually deployed funds/resources (into repairs or proving new facilities/buildings that could have been used for other development purposes.

On a general note, the findings of this investigation are in line with many scholarly reports on violent crises elsewhere. For instance, it has been reported that the overall consequences of violent crises are threat to security of lives, properties, domestic and foreign investments with continuous capital flight and loss of confidence in the economy (Babangida, 2002; Saheed and Egwaikhide, 2012). Some scholars have also buttressed that one of the significant means to economic development of a given society or nation-state is the human capital - that is, the quality of human resources (Morris, 2010; Saheed and Egwaikhide, 2012; Akwara and Charles, 2014). To them, it represents the subject, object and the process of socio-politically and economically building the society. Similarly, it has been succinctly asserted that Nigeria 
is blessed not only in terms of natural resources, but also human resources. Saheed and Egwaikhide (2012) observed that violent crises in Nigeria have not only resulted in material loses, but also human loses.

In the same vein, Saheed and Egwaikhide (2012) espoused that as human resources are the engine of economic development, so also is the growth and development of educational sector crucial to human resources training and development; hence, every society or nation is striving to provide the necessary amenities to enhance the standard of education of its citizens. However, the attainment of this vital objective could be hampered by incessant closure of schools and high institutions in conflict prone areas. The authors stressed that violent crises disrupt academic activities in the affected areas, while the education of pupils/students whose parents/guardians are forced to relocate are seriously affected. In addition, resettlements in new environment may take a long period, while time is wasted in search of better economic condition for the family and new schools for the students which may negatively impact the academic performance of the students cum economy status of the family and the society on the long-run. The situation in Wukari LGA is not quite different from the above scenario. As earlier noted, not only did the crisis truncated economic activities and development, it also distorted the fast-growing academic activities as well as social and infrastructural development of the area.It is important to note that this paper observed that from the year 2012 when the former Late Governor Dan-Baba Dan-Fulani Suntai's plane crash in October, 2012, the Southern part of the state including Wukari LGA has witnessed various forms of violent crisis with its attendant consequences; ranging from political, social and economic wellbeing of the people as well as infrastructural development of the area.

Another negative social effect of the crises was increased rate of unemployment which has led many average people living in the areas to be involved in various forms of criminalities. This is because most of the people who have eventually found themselves in the new unfortunate immoral enterprise were unexpectedly (and without any futuristic plan) laid-off from their normal source of income, mostly from private (business) and agricultural sectors. Moreover, most of the youths who participated in the armed conflict, joined in looting and exploiting their victims. These kinds of criminal activities continued even after the crises. It is not surprising then, to assert that the economic potential of crisis prone areas is not fully realized due to persistent crises and other forms of threats. Mawardi (2006) argued that most production (economic activities) in such areas are disrupted and those who attempt to establish businesses, sell products, etc. face security threats and barriers such as illegal taxes/fees imposed by some locales and/or security personnel. Similarly, dayto-day activities are interrupted, affecting daily income of individuals or households and also leading to hike in price of goods in the market (Ogbonnaya and Ehigiamusoe, 2013:3). In such unplanned situation, the people begin to experience discomfort due to low income/purchasing power, insufficient or lack of good water, food, electricity as well as other essential goods and services. No wonder then Solimano (2005) noted that any protracted situation of such, engendered underdevelopment with its untold effects. Therefore, there is indeed, the need for improvement on security, socioeconomic welfare of the people, public enlightenment/sensitization on the looming danger of violent crisis and management of unemployment if violent crises are to be managed effectively in every segment of the country.

Summarily, almost all the literature reviewed in this work suggested that violent crisis and development are two parallel lines that can never meet. Conflicts/crises situation does not allow for any meaningful and consolidated development. It is also obvious that violent crisis often resulted to destruction of lives, private properties as well as government institutions, and affects cultural heritage of the people; and above all, it stalls the socio-economic development and negatively impinges on the general wellbeing of the people of Wukari LGA. More often than not, violent crises affect economic outcome mostly through the destruction of physical and human capital, shifts in public spending and private investment, as well as the disruption of other forms of economic activities and social life. It is worthy of note that the specific impacts of violent crisis depend on each crisis' singular characteristics: it is not just the type of the crisis, but also its intensity, duration and geographical spread that shapes its consequences.

Generally, the negative economic impact of violent crisis is not limited to the affected areas, as the effect often spills over to neighboring villages, towns, regions or even countries as the case may be. The flows of internally displaced persons (IDPs) usually increase labour supply, but reduce per capita incomes, trade flows are disrupted, government spending is diverted to non-production security measures, direct business investments might be shifted away from the entire areas perceived as insecure; and in environment where the dwellers are predominantly famers, farming activities are reduced drastically or halted. These, by implication affect the economic status of individuals as well as undermine economic development/progress.

\section{Conclusion}

Based on the study carried out, it is obvious that violent crisis is almost always accompanied with pathetic stories of destruction of both lives and valuable properties. Some individuals were left maimed/disfigured, with valuable properties looted while others were extorted. In some cases, survivors flee from the areas to never return again while others come back to start life all over again haven lost their personal belongings. This signifies that many people were rendered homeless with the only option to either find shelter with their relatives elsewhere or to be at Internally Displaced Persons (IDPs) camps. The findings of the study showed that the significant relationship between Wukari LGA crises of $2012-2017$ and economic development in the area was a negative one. This is because the aggregate mean derived from responses on the null hypothesis with4.84was rejected as it was lower than aggregate mean value of 10 compared to that of the alternate hypothesis with 64.21which was accepted as it was far above the aggregate mean value of 10 .

Drawing from the research findings, therefore, the paper submits that sustainable socioeconomic development can hardly be achieved in a violent crisis situation/area; be it at the societal level (as the case in Wukari LGA) or national level. Thus, the study established that underdevelopment and indeed, the retrogressive state of economic prevalent in 
Wukari LGA today is not only a problem of lack of economic resources or industrial investment, but also largely associated with the condition of the environment (violent crises) as well as social relations that exist between/among the people.

Finally, this study agreed with other studies elsewhere and submits that the consequences of violent crises are immediate threat to security of lives and properties, agricultural/business investments with continuous capital flight and the overall loss of confidence in the economy which inevitably result to increase level of poverty that transmit negatively to economic development in the area. Therefore, it is apt to conclude that no one can make any meaningful development without peace; whether at individual or social group level, community or national level, powerful or weak society, etc.

\section{Recommendations}

In order to ensure lasting peace/harmonious coexistence that can invigorate and consolidate sustainable development in Wukari Local Government Area, the following suggestions are put-forward:

- Government at all levels, non-governmental organizations (NGOs) and/or philanthropists should establish/promote social reorientation programme with the aim of transforming human capital for national development; this may involve making/implementing informed policies that will check conflicts and address the problems of the people; which include: Provision of basic social amenities, mass academic scholarship, provision of job opportunities, establishment of skills acquisition centres, programmes, etc. as well as implement such other relevant policies and programmes that can address poverty, youth unemployment, and gender inequality in the study area and other parts experiencing similar challenges in the country. This is because if these youths are not productively engaged could be used as instrument for violence. Thus, it is imperative and pertinent that they be meaningfully engaged and bring out the best in them. A disciplined, productive and law-abiding citizen (youth) can create a brighter future for himself and his/her society, particularly Wukari LGA and Nigeria as a whole, while a lawless, violent and indulgent youth becomes a potent grave threat to national security and socio-economic development of his/her environment;

- There should be proper and constant conflict resolution enlightenment and adequate education/sensitization of the populace on the looming dangers of violent crisis to both human existence and socioeconomic development in Wukari LGA, as well as the need to embrace peace at all times and why the rule of law must be observed in dealing with virtually every contending issues in the society.

- In line with the above, the study also recommends that a participatory or people driven approach to conflict management should be adopted, whereby the campaign team will constitute representatives of the governments, and the communities especially those who have been adequately counseled to accept the realities of the situations. The participatory approach to conflict management is no doubt an invaluable tool which would enable a wide cross-section of people share information and opinion about their lives and environment. People (Youths, Women and Elder councils) who under normal circumstances are voiceless and powerless in the community are empowered to gain confidence and to speak out. The face-to-face interaction which provides/creates the opportunity for policy makers to gain an understanding of the issue at stake and to develop community trust and confidence for the government and its interventions should be adopted.

- $\quad$ Regarding the phenomenon of nomadic herdsmen-farmers clashes in some of the study area, government should play active role by way of legislation to restrict movement of pastoralists with the aim of ensuring good health of the nomads as well as preventing these animals from causing destruction to food crops that usually degenerated to the problem of foods security. This will also reduce the chances of endangering these animals by humans (rustlers) and thereby reducing violent conflicts in the process. This can be achieved by building and promoting the construction of ranches which will be fenced or demarcated and reserved for raising cattle, sheep, goats, horses, donkeys, etc. The most important aspect of this is that both the government and the governed would have "cut-off the bone of contention" between herdsmen and farmers and can as well generate revenue from this measure if properly harnessed (managed). Moreover, the children of pastoralists are denied access to formal education due to frequently being on the move; this creates unsustainable development;

- In terms of ethno-religious bigotry, leaders in all spheres of life within Wukari LGA(especially religious, community/traditional institutions) should propagate and ensure mutual understanding, tolerance and respect for members of other ethnic or religious groups, irrespective of the differences in culture, origin, belief or creed. Meanwhile, government/its officials or agencies should ensure strict adherence to the constitutional provision against "discrimination" and that which stipulates that: "The Government of the Federation or of a State shall not adopt any religion as State Religion" (CFRN, 1999);

- Above all, whenever there is dispute or disagreement which is commonly associated with man, dialogue should be allowed to prevail over the language of violent crisis. A robust, vibrant social communication and dialogue model should be put in place to bridge the current socio-cultural gaps noticeable in the area. This could be done through the activation of social networks such as clubs' membership, sports, work place ties, alma-mater ties,recreation centres across the local government with the aim of fostering peace and unity among members of different groups in the study area.

The paper believes that these measures may cushion/allay structural causes of violent crisis and may bring about lasting peace that can guarantee progress and development of the people.

\section{References}

i. Abdulbarkindo, A. \& Alupse, B. (2015). Violent Conflict in Divided Societies: The case study of violent conflict in Taraba State (2013 - 2015).World Watch Research, Open Doors International, Netherlands, pp. 6 - 68. 
ii. Adebayo, R. I. (2010). Ethno-religious crisis and the challenges of sustainable development in Nigeria. Journal of Sustainable Development in Africa, 12(4): 213 - 217.

iii. Adeniyi, M. O. (1993). Religion and Politics: An eye bird's view of development in Nigeria. In: R. D. Abubakar (Eds.), Religion and Politics in Nigeria. Ilorin: NASR.

iv. Ajayi, A. J. J. and Ian, E. (1978). A Thousand Years of African History. Lagos: Thomas Nelson and Sons.

v. Ake, C. (1991). 'Political Economy of Crisis and Underdevelopment in Africa. In: Ihonvbere, J., Selected Works of Claude Ake. Lagos: JAD Publishers.

vi. Akhakpe, I., Fatile, O. J. \& Igbokwe-Ibeto, F. (2012). Local Government and the challenges of Community and Rural Development in Nigeria: The Way Forward. International Journal of Asian Social Service, 11(VII):803-819.

vii. Akwara, A. F. and Charles, A. (2014). Counting the costs: Ethnic violence versus human and capital flight from Wukari local government area of Taraba State, Nigeria. Intern. J. Res. in Applied, Natural \& Social Sciences, 2(11): $121-135$.

viii. Alegbeleye, G. I. (2014). Ethno-religious crisis and socio-economic development in Nigeria: Issues, challenges and the way forward. Journal of Policy \& Development Studies, 9(1): 139 - 148.

ix. Alemika, E. O. (2002). Sociological analysis of ethnic and religious conflicts in the middle belt of Nigeria in ethnoreligious conflicts and democracy in Nigeria. Challenges, Human Rights Monitor, Kaduna.

x. Ali, A. Y., Lagan, A. N., Joshua, S., Peterside, Z. B. \& Danjuman, A. K. (2014). An assessment of the effects of communal conflicts on production and income levels of people living in Takum and Ussa Local Government Areas of Taraba State, Nigeria. The Intern. J. Sci. \& Technoledge, 2(7): 308 - 314.

xi. Ambe-Uva, T. N. (2010). Identity politics and the Jos crisis: Evidence, lessons and challenges of good governance. African Journal of History and Culture (AJHC), 2(3): 42 - 52.

xii. Anderson, M. L. \& Taylor, H. F. (2009). Sociology: The Essentials. Three Major Perspectives in Sociology Belmont, CA: Thomson Wadsworth. http://www.cliffsnotes.com/study_guide/ topicArticleId-26957.html.

xiii. Aremu, M. O., Oko, O. J. \& Andrew, C. (2017). Ground water and river quality assessment for some heavy metals and physicochemical parameters in Wukari town, Taraba State, Nigeria. International Journal of Sciences, 6(5): 73 $-80$.

xiv. Aver, T. T., Nnorom, K. C. \& Targba, A. (2013). Political violence and its effects on social development in Nigeria. Int. J. Humanities \& Social Sci., 3(17): $261-266$.

xv. Babangida, I. B. (2002). Ethnic Nationalities and the Nigerian State: The Dynamic and Challenges of Governance in a Plural Nigeria. In: Distinguish Annual Lecture; National Institute for Policy and Strategic Studies, Kuru, Nigeria.

xvi. Bagaji, A. S. Y. (2012). Boko Haram and the recurring bomb attacks in Nigeria: Attempt to impose religious ideology through terrorism. Cross-Cultural Communication, (8)1: 33 - 41.

xvii. Black, J. \& Champion, D. (1976). Methods and Issues in Social Research. New York: John Willey and Sons.

xviii. Blattman, C. \& Miguel, E. (2010). Civil War. Journal ofEconomic Literature, 48(1): 3 - 57.

xix. CFRN (1999). The Constitution of the Federal Republic of Nigeria 1999. Subsidiary Legislation: CAP. C23 L.F.N., 2004. Retrieved April 06, 2014.

xx. Charles, A. (2016). Peace and conflict studies: Conceptual explanations and typologies. In: Nwanegbo, C. J. \& Banke, S. A. (ed.). "Peace and Conflict Studies: An Introduction", Vol. 1. Traeces Printing \& Publishing Company, Makurdi, Nigeria.

xxi. Charles, A., Andeshi, C. A. \& Wununyatu, D. (2014). War economy of ethno-religious crises: A Study of the Wukari crises of Taraba State, Nigeria. International Journal of Peace \& Conflict Studies (IJPCS), 2(1): 21 - 28.

xxii. Cochran, W. G. (1963). Sampling Techniques; 2nd Ed., New York: John Wiley and Sons, Inc.

xxiii. Collier, P. \& Hoeffler, A. (1998). On economic causes of civil war. Oxford Economic Pap., 50: 563 - 573.

xxiv. Drukkman, D. (1993). An Analytical Research Agenda for Conflict and Conflict Resolution. In: Dennis J. D. Samdole and Hugo Vander Marwe (Eds.), Conflict Resolution Theory and Practice: Integration and Application. Manchester and New York: Manchester University Press.

xxv. Emeh, I. E. (2013). Dependency theory and Africa's underdevelopment: A paradigm shift from pseudointellectualism: The Nigerian perspective. International Journal of African \& Asian Studies, 1: 116 - 128.

xxvi. Fearon, J. D. and Laitin, D. D. (2003). Ethnicity, insurgency, and civil war. Am. Pol. Sci. Rev., 97(1): 75 - 90.

xxvii. Folger, J. P. (1997). Working Through Conflict: Strategies for Relationships. New York.

xxviii. Galtung, J. (2011). Peace and Conflict Studies as Political Activity. In: Thomas, Jessica and Sean's “critical Issue in Peace and Conflict Studies: Theory, Practice and Pedagogy" (ed.). Lanham, Lexington Books.

xxix. Godwin, S. M. (2006). Introduction to Conflict Resolution Processes II. Lagos: National Open University of Nigeria.

xxx. Joshua, S. (2013). Democracy \& violent conflicts in Nigeria: Implications for national development. African Research Review: An Int'l. Multidisciplinary Journal, Ethiopia, 7(3): 324 - 339.

xxxi. Kothari, C. R. \& Garg, G. (2014). Research Methodology: Methods and Techniques. Third Edition, New Age International (P) Ltd., Publishers.

xxxii. Marx, K. \& Engels, F. (1848). The Communist Manifesto. New York: International Publishers Company. Available at http://www.marxists.org/archive/marx/works/1848/ communist manifesto/ch01.htm

xxxiii. Mawardi, S. (2006). Community Synthesis Report: Kampong Pisang, Ternate, North Maluku, Indonesia. The SMERU Research Institute, Jakarta.

xxxiv. Nnadozie, O. U. (2006). External forces, democracy and underdevelopment in Nigeria: A prognosis. A paper presented at Two-Day International Workshop on Global and Regional Hegemonic Dilemmas in the South held in Bangkok, Thailand, 2006. 
xxxv. Nwanegbo J. (2012). Internal conflicts and African development: The Nigerian experience. J. Humanities \& Social Sci., 5(4): 22-33.

xxxvi. Nwanegbo, J., Odigbo, J. \& Ochanja, N. C. (2014). Citizenship, indigeneship and settlership crisis in Nigeria: Understanding the dynamics of Wukari crisis. J. Res. Peace Gend. Dev., 4(1): 8-14.

xxxvii. Ogbonnaya, U. M. \& Ehigiamusoe, U. K. (2013). Niger Delta Militancy and Boko Haram Insurgency: National Security in Nigeria. Global Security Studies, Vol. 4(3).

xxxviii. Onimode, B. (1985). An Introduction to Marxist Political Economy. London: Zed Books.

xxxix. Onwe, S. O., Nwogbaga, D. M. E. \& Nwakamma, M. C. (2015). Effects of social conflicts on the sustainable development of Ebonyi State: A study of Ezillo-Ezza Ezillo conflicts (2008-2014). Open-Access Journals: Developing Country Studies, 5(3): 78 - 86. http://www.iiste.org/journals/.

xl. Oyedolapo, B. D. (2013). Fundamental of Peace Studies and Conflict Resolution. Lagos: National Open University of Nigeria.

xli. Ray, D. \& Esteban, J. (2017). Conflict and Development. Annual Review of Economics, 9: 263 - 293.

xlii. Raymond, C. T. \& Rajat, G. (2002). Understanding Ethnic Conflict: The International Dimension. New York: AddisonWesley Educational Publisher.

xliii. Resnick, S. \& Wolff, R. (1978). Marxian Crisis Theory: Structure and Implications. Review of Radical Political Economics, 10(1): 47 - 57.

xliv. Richmond, W., Sharon, R. W. \& Cirecie, W. O. (2010). Multiculturalism, conflict transformation and peacebuilding: Practitioner and client working together. In: Candice, T.; Conflict Resolution and Peace Education: Transformation Across Disciplines (ed.). New York, Palgrave Macmillan.

xlv. Rodney, W. (1972). How Europe Underdeveloped Africa. Washington DC: Howard University Press.

xlvi. Roger, M. G. (2006). No War, No Peace: The Rejuvenation of Stalled Peace Processes and Peace Accords. New York: Palgrave Macmillan.

xlvii. Saheed, Z. S. \& Egwaikhide, C. I. (2012). Impact of social crises on economic development: Theoretical evidence from Nigeria. American Intern. J. Contemporary Res., 2(6): 176 - 184.

xlviii. Shabi, O. and Awe, K. (2001). Understanding Society and Social Relations. Lagos: Concept Publications.

xlix. Solimano, A. (2005). Political Crises, Social Conflict and Economic Development. MPG Books Ltd, Bodmin, Cornwall, UK.

l. Todaro, M. (1992). Economic for a Developing World: An Introduction to Principles, Problems and Policies for Development. London: Longman Group Ltd.

li. World Bank (1989). Governance and Development. World Bank, Washington DC. 